NBER WORKING PAPER SERIES

\title{
GLOBALIZATION IN \\ LATIN AMERICA BEFORE 1940
}

\author{
Luis Bértola \\ Jeffrey G. Williamson \\ Working Paper 9687 \\ http://www.nber.org/papers/w9687
}

\section{NATIONAL BUREAU OF ECONOMIC RESEARCH 1050 Massachusetts Avenue Cambridge, MA 02138}

May 2003

Chapter draft for the forthcoming Cambridge Economic History of Latin America eds. Victor BulmerThomas, John Coatsworth, and Roberto Cortés Conde (Cambridge: Cambridge University Press). We are grateful for critical comments and encouragement from John Coatsworth, Roberto Cortés Conde, Carola Frydman, José Antonio Ocampo, Gabriel Porcile, Leandro Prados and Julia Sarreal. In addition, we also acknowledge the excellent research assistance of David Clingingsmith and Silvana Maubrigades. Williamson acknowledges with pleasure financial support from the National Science Foundation SES-0001362.The views herein are those of the authors and not necessarily those of the National Bureau of Economic Research.

(C2003 by Luis Bértola and Jeffrey G. Williamson. All rights reserved. Short sections of text not to exceed two paragraphs, may be quoted without explicit permission provided that full credit including Cnotice, is given to the source. 
Globalization in Latin America Before 1940

Luis Bértola and Jeffrey G. Williamson

NBER Working Paper No. 9687

May 2003

JEL No. F1, N7, O2

\section{$\underline{\text { ABSTRACT }}$}

How much of the good growth performance in Latin America between 1870 and 1913 can be assigned to the forces of globalization? Why was industrialization so weak? Why was inequality on the rise? This paper offers an answer to these questions. It starts by exploring the disadvantages associated with geographic isolation from world markets and the transport revolutions that helped liberate Latin America from that isolation, a pro-global force. It then asks how independence contributed to massive de-globalization during the decades of "lost growth" between the 1820s and the 1870s. Next, it documents what happened to the external terms of trade in Latin America between 1820 and 1950: from the 1890s onwards the terms of trade deteriorated, but it also underwent spectacular improvement before the 1890s, suggesting that it had something to do with the "“fairly fast"” Latin America growth during so much of the belle époque. While booming relative prices of exports certainly fostered trade, policy suppressed it: tariff rates were higher in Latin America than almost anywhere else in the world between 1820 and 1929, long before the Great Depression. The paper then asks why. The answer is to be found mainly with revenue needs rather than with some precocious import substitution policy. High tariffs still had a powerful protective effect, regardless of motivation. However, protective policy was modified by those powerful and positive terms of trade shocks, yielding on net weak early industrialization. Finally, the paper documents that inequality rose in most of Latin America up to World War I, while it fell thereafter. The correlation between globalization and inequality is likely to have been causal.

Luis Bértola

Economic and Social History Programme

Universidad de la República

Montevideo, Uruguay

lbertola@fcsum.edu.uy
Jeffrey G. Williamson

Department of Economics

216 Littauer Center

Harvard University

Cambridge, MA 02138

and NBER

jwilliam@kuznets.fas.harvard.edu 


\section{Globalization and Growth}

Some describe the first half of the $19^{\text {th }}$ century as decades of lost Latin American growth while the region struggled with independence and the aftermath. Its growth performance in the second half of the 20th century was also disappointing. By comparison, during the half century between the 1860 s and the 1910s the Latin American economies performed fairly well: they kept pace with European growth rates, grew more than other peripheral regions, but grew less than the big winners of the period, the US and those European countries catching up with Britain. ${ }^{1}$ The term "fairly well" may understate Latin American growth since, after all, it took place during a century that created a truly huge economic gap between core and the rest of the periphery (Pritchett 1997).

Table 1 documents that performance for real per capita income and purchasing-power-parity adjusted real wages of unskilled urban workers, both relative to Great Britain. Using the macro economists' rhetoric, there was some Latin American "catching up" on the hegemonic industrial leader in Europe: per capita income in Latin America rose from 38 to 42 percent of Britain. Since Britain was losing that leadership to some powerful latecomers, perhaps a better comparison is with a more inclusive European industrial core - Britain, France and Germany: here, Latin American performance is a little less impressive, its relative position to that of the fast-growing core falling from 53 to 51 percent. Another relevant comparison is between Latin America and the source of its European immigrants - Iberia and Italy: here, Latin America improved its position from near-parity, with income per capita about 97 or 98 percent of Latin Europe, to a 5 percent advantage. Since it was a relatively labor-scarce and resourceabundant region compared with Europe (especially Latin Europe), real wage comparisons tend to favor Latin America much more than do per capita income comparisons. Thus, while Latin American per capita incomes were about 51 percent of the European core in 1913, real wages were about 59 percent of the

\footnotetext{
${ }^{1}$ Comparisons with the United States are common in the literature, but since nobody matched US growth performance in its leap to world industrial dominance over these six decades, such comparisons seem irrelevant.
} 
core, an 8 percentage point difference. The difference in 1929 was even bigger, 15 percentage points. Finally, not every Latin American country grew "fairly fast." Indeed, economic gaps within the region widened considerably: while in 1870 the per capita GDP of Brazil and Mexico were about 55 percent of that of Argentina, by 1913 they were reduced to 22 and 39 percent, respectively (Maddison 2001; see also Leandro Prados, “The Economic Consequences of Independence,” this volume).

How much of this economic performance between 1870 and 1913 can be assigned to the forces of globalization? This chapter will ponder this question, but it will do so only by exploring the impact of international trade. Other chapters in this volume have done the same for the mass immigrations from Latin Europe (Blanca Sánchez-Alonso, "Labor and Immigration," this volume) and for capital inflows from Britain, the US and elsewhere (Alan Taylor, "Foreign Capital in Latin America," this volume). The three chapters should be read together since capital flows, immigration, trade and the policies influencing all three cannot really be assessed independently.

This chapter covers the following territory: The next section explores the important disadvantage associated with isolation from regional and world markets and the transport revolutions that helped liberate so much of Latin America from that isolation. Section 3 deals with the immense variety in Latin America by focusing on how the distinctly different country resource endowments unfolded during the period, and their impact on export specialization and trade. Section 4 connects with another chapter in this book (Prados, this volume), asking how independence might have caused massive de-globalization during those decades of "lost growth" between the 1820 s and the 1870 s. Next, we document what happened to the external terms of trade (the ratio of export to import prices) in Latin America between 1820 and 1950. The section replicates the period of deterioration from the 1890s onwards first popularly noted by Raúl Prebisch. But it also documents the spectacular improvement in the terms of trade before the $1890 \mathrm{~s}$, suggesting that it had something to do with the "fairly fast" Latin America growth during so much of the belle époque. Booming relative prices of exports certainly fostered trade, but trade policy suppressed it: tariff rates were higher in Latin America than almost anywhere else in the world between 1820 and 1929, 
long before the Great Depression. Section 6 asks why. The answer is to be found mainly with revenue needs rather than with some precocious import substitution and industrialization policy, but high tariffs still must have had a powerful protective effect. Section 7 pursues these issues further by assessing the connections between export-led growth and weak early industrialization. The penultimate section shows that inequality rose in most of Latin America up to World War I, while it fell thereafter. The correlation between globalization and inequality is likely to have been causal, not spurious. The final section offers a research agenda for the future.

\section{Distance, Transport Revolutions and World Markets ${ }^{2}$}

In The Tyranny of Distance (1966), Geoffrey Blainey showed how isolation shaped Australian history. Early in the 19th century, distance isolated both Australia and Asia from Europe where, after all, the industrial revolution was unfolding. Later in the 19th century, transport innovations began to erode the disadvantages of geographic isolation, although not completely. The completion of the Suez Canal, cost-reducing innovations on sea-going transport, and railroads penetrating the interior all helped liberate that part of the world from the tyranny of distance. ${ }^{3}$

Should this account about economic isolation apply to much of $19^{\text {th }}$ century Latin America as well? Before the completion of the Panama Canal in 1914, the Andean economies -- Chile, Peru and Ecuador -- were seriously disadvantaged in European trade. ${ }^{4}$ And prior to the introduction of an effective railroad network, the landlocked countries of Bolivia and Paraguay were at an even more serious disadvantage. This was also true of the Mexican interior (Coatsworth 1981), the Argentine interior (Newland 1998), the Colombian interior (Ocampo 1994: pp. 185-8) and elsewhere. Thus, the economic distance to the European core varied considerably depending on location in Latin America. A close

\footnotetext{
${ }^{2}$ This section draws heavily on Williamson (1999).

${ }^{3}$ This focus is certainly consistent with the new economic geography (Krugman 1991; Krugman and Venables 1990,
} 
observer of early 19th century Latin America, Belford Hinton Wilson, reported in 1842 the cost of moving a ton of goods from England to the following capital cities (in pounds sterling): Buenos Aires and Montevideo 2; Lima 5.12; Santiago 6.58; Caracas 7.76; Mexico City 17.9; Quito 21.3; Sucre or Chuquisca, 25.6; and Bogatá 52.9. The range was huge, with the costs to Bogotá, Chuquisca, Mexico City, Quito, and Sucre nine to twenty-seven times that of Buenos Aires and Montevideo, both well placed on either side of the Rio de la Plata (Brading 1969: pp. 243-4). Furthermore, and as Leandro Prados has pointed out elsewhere in this volume (Prados, this volume: Table 4), most of the difference in transport costs from London to Latin American capital city was the overland freight from Latin American port to interior capital.

Distance, geography and access to foreign markets explained a third of the world's variation in per capita income as late as 1996 (Redding and Venables 2000; Overman, Redding and Venables 2001). Not surprisingly, therefore, geographic isolation helped explain much of the economic ranking of Latin American republics in 1870 too, with poor countries most isolated: Argentina and Uruguay at the top; Cuba and Mexico next; Colombia and southeast Brazil third; and Peru, Ecuador, Bolivia and Paraguay at the bottom. Of course, there were other factors at work too, like institutions, demography, slavery and luck in world commodity markets. After all, Potosí was a very rich colonial enclave in spite of its relative isolation, and the Brazilian Northeast was very poor in spite of its favorable location vis a vis European markets. Still, geography played a huge role.

The most populated areas under colonial rule were the highlands. The Andean capital cities and Mexico City were far from accessible harbors, thus increasing transport costs to big foreign markets. This was the case of Bogotá, Quito, Santiago, La Paz, Mexico City, and even Caracas, the latter located near the coast but with difficult harbor access. In contrast, the Latin American regions bordering on the Atlantic, with long coastlines and good navigable river systems, have always been favored (although

1995; Gallup and Sachs 1999; Acemoglu et al. 2001).

${ }^{4}$ They were, of course, well placed for the Pacific Coast US market. 
Spanish colonial policy often served to diminish those natural advantages). These include Argentina, Uruguay, Brazil, Cuba and the other Caribbean islands. These nations may have failed for other reasons, but geographic isolation certainly wasn't one of them. The harbors were more conveniently located in relation to the lowlands which were suitable for tropical agriculture, as was the case for sugar, coffee, tobacco, cacao, rubber, and other tropical products. The main constraint to expansion facing those landabundant regions was access to labor, not geography and access to foreign markets. Slavery was the most common solution to the problem along Colombia's Caribbean coast, in the lowlands of Ecuador near Guayaquil, in the Peruvian coast near El Callao, in the Caribbean and of course in Brazil.

Prior to the railway era, transportation was either by road or water, with water being the cheaper option by far. Thus, investment in river and harbor improvements increased everywhere in the Atlantic economy. Steamships were the most important contribution to 19th century shipping technology, and they increasingly worked the rivers and inland lakes. In addition, a regular trans-Atlantic steam service was inaugurated in 1838 , but it must be said that until 1860 steamers mainly carried high-value goods similar to those carried by airplanes today, like passengers, mail and gourmet food.

The switch from sail to steam may have been gradual, but it accounted for a steady decline in transport costs across the Atlantic (Harley 1988). A series of innovations in subsequent decades helped make steamships more efficient: the screw propeller, the compound engine, steel hulls, bigger size and shorter turn-around time in port. Before 1869, steam tonnage had never exceeded sail tonnage in British shipyards; by 1870 , steam tonnage was over twice as great as sail, and sail tonnage only exceeded steam in two years after that date.

Refrigeration was another technological innovation with major trade implications. Mechanical refrigeration was developed between 1834 and 1861, and by 1870 chilled beef was being transported from the United States to Europe. In 1876, the first refrigerated ship, the Frigorifique, sailed from Argentina to France carrying frozen beef. By the 1880s, South American meat was being exported in large quantities to Europe. Not only did railways and steamships mean that European farmers were faced 
with overseas competition in the grain market, but refrigeration also deprived them of the natural protection distance had always provided local meat and dairy producers. The consequences for European farmers of this overseas competition was profound (O’Rourke 1997; Williamson 1997).

Transport cost declines from interior to port, and from port to Europe or to the East and Gulf Coast of the United States, all ensured that Latin America became more integrated into world markets. The size of the decline around the Atlantic economy can be seen graphically in Figure 1. What is labeled the North index (North 1958) accelerates its fall after the 1830s, and what is labeled the British index (Harley 1988) is fairly stable up to mid century before undergoing the same, big fall. The North freight rate index among American export routes dropped by more than 41 percent in real terms between 1870 and 1910. The British index fell by about 70 percent, again in real terms, between 1840 and 1910. These two indices imply a steady decline in Atlantic economy transport costs of about 1.5 percent per annum, for a total of 45 percentage points up to 1913. One way to get a comparative feel for the magnitude of this decline is to note that tariffs on manufactures entering OECD markets fell from 40 percent in the late 1940s to 7 percent in the late 1970 s, a 33 percentage point decline over thirty years. This spectacular postwar reclamation of free trade from interwar autarky is still smaller than the 45 percentage point fall in trade barriers between 1870 and 1913 due to overseas transport improvements. Furthermore, the role of railroads was probably more important. For example, between 1870 and 1913, freight rates in Uruguay fell annually by 0.7 percent on overseas routes, but by 3.1 percent along the railroads penetrating the interior, four times as big (Bértola 2000: Table 4.1, p. 102). Railroads were vital in developing exports, but they also served to integrate the domestic market.

Though impressive, it is important to note that the impact of the transport revolution on freight rates was unequal along different routes. As Juan Oribe Stemmer (1989: p. 24) has shown, overseas freight rates fell much less along the southward leg than along the northward leg, and the fall along the latter does not seem to have been as great as that for Asian and North Atlantic routes. The difference may have a great deal to do with the degree of competition among carriers and the role of shipping conferences 
in setting freight rates. In any case, the northward leg was for the bulky Latin American staple exports -like beef, wheat and guano, the high-volume low-value primary-products whose trade gained so much by the transport revolution. The southward leg was for Latin American imports -- like textiles and machines, the high-value low-volume manufactures whose trade gained much less from the transport revolution.

Still, these transport innovations significantly lowered the cost of moving goods between markets, an event that should have fostered trade. And trade certainly boomed in Latin America (BulmerThomas 1994: Table A.2.1, p. 439). The share of Latin American exports in GDP was around 10 percent in 1850 , while in 1912 it was 25 percent. Still, the volume of trade is not by itself a very satisfactory index of commodity market integration. It is the cost of moving goods between markets that counts. The cost has two parts, that due to transport and that due to man-made trade barriers (such as tariffs). The price spread between markets is driven by changes in these costs, and they need not move in the same direction. It turns out that tariffs in the Atlantic economy did not fall from the 1870 s to World War. Instead, it was falling transport costs which provoked globalization. Indeed, rising tariffs in Europe were mainly a defensive response to the competitive winds of market integration as transport costs declined (O'Rourke and Williamson 1999: Chps. 3 and 6). We shall see below that the rise in tariffs was even greater for Latin America.

It might be well to repeat this fact: while the first global century was certainly more "liberal" than the autarky that followed after 1914, it was still a period of retreat from openness, as we shall see again below. Yet, the decline in international transport costs overwhelmed the retreat from free trade, thus accommodating the trade boom between center and periphery.

\section{Resource Endowments, Specialization and Trade}

\section{Are Endowments Fate?}

This question, used by James Robinson (2000) to title a recent paper, has motivated much of the 
Latin American historiography in the last four decades. Do factor endowments best explain the per capita income gaps within the region exhibited at the beginning of the first global century? Do they best explain why the gaps increased thereafter?

In his survey for the Cambridge History of Latin America, William Glade offered a concise overview of Latin American diversity: "Between 1870 and 1914 Latin America not only exhibited increasing regional differentiation but also evolved quite a different endowment of factors of production, thanks to the demand-induced (but not solely demand constrained) development of the period. The resource patterns which underlay the region's economies on the eve of the First World War differed notably from those on which the economic process rested at the outset of the period." ${ }^{5}$ Glade adopted an intermediate position between two conflicting approaches to understanding Latin American development (Glade 1986: pp. 49-50). He used the dual economy approach to describe how the sources of economic transformation were first limited to enclaves exhibiting market-oriented production. As time went on, foreign demand, the transport revolution and the integration of domestic factor markets made the withincountry institutional topography more uniform. Countries where the transformation was incomplete by World War I were ones where the original size of the export-sector was small, or where the export sector had limited capacity to replace traditional with capitalist institutions elsewhere in the economy, or both. Thus, incomplete transformation is explained by weak diffusion between sectors.

A group of revisionists argue, on the contrary, that this "dual economy" approach fails to give play to important forces that may have suppressed or even reversed diffusion. Instead, these revisionists emphasize that increased market-oriented production often strengthened coercive anti-market relationships rather than weakened them. Exactly how these forces evolved depended on initial endowments and related institutions. Different typologies have been proposed, in which endowments and institutions are assigned varying levels of importance, but in which globalization always has a powerful

\footnotetext{
${ }^{5}$ Glade (1986: pp. 46-7). The Cambridge History of Latin America has other excellent surveys on this factor endowment and institutional diversity in Latin America (Bauer 1986; Moreno Fraginals 1986). The contributions by
} 
influence on outcomes. There are three camps: those who see the causality as running from institutions to endowments; those who see the causality as running from endowments to institutions; and those eclectics who see a two-way causality.

Among the eclectics, Celso Furtado (1974: pp. 50-3) stands out. He suggested it might be useful to think in terms of three Latin American regions: (1) scarcely populated countries of temperate climate exporting goods similar to those produced in Europe, offering an overseas frontier where high wages attracted free labor; (2) traditional societies specializing in tropical agrarian products which were labor intensive, the prices of which were relatively low compared to imports, and the wages in which were even lower; (3) countries exporting minerals, the production of which experienced important productivity improvements which, however, were limited to enclaves controlled by foreign firms. The main institutional aspects considered in this typology are the concentration and nationality of property ownership, the existence of coercive mechanisms for extracting labor, the extent of the market, and attitudes towards technical change. Osvaldo Sunkel and Pedro Paz (1970: pp. 321-43) added more institutional variables to the typology and Fernando Cardoso and Enzo Faletto (1979) extended the approach even farther: to them, economic performance was mainly dependent on whether the ownership of natural resources was in the hands of numerous domestic agents -- like land in the Río de la Plata area, or in the hands of a few foreign firms -- like minerals in the Andean and Mexican regions. For these eclectics, the implications for workers' living standards, economic diversification and inequality were profound.

Institutional determinists criticized the eclectics from a Marxist point of view. Thus, Augustin Cueva (1977) insisted that the persistence of pre-capitalist relations limited the extension of free labor, which, in turn, determined whether high wages, expanding domestic markets and rapid technical change would emerge. Cardoso and Pérez Brignoli (1979) also contributed to this institutional-determinist

Alan Taylor and Blanca S $\varangle$ chez-Alonso to the present volume are also helpful in understanding the availability of foreign labor and capital to Latin America during the long century from Independence to Great Depression. 
critique, with a typology very similar to Furtado's: (1) the development of capitalism in new settler economies; (2) the transition to capitalism in the Andean and Meso American economies which evolved differently due to an initial environment created by the interaction between European feudalism and native institutions; and (3) the transition to capitalism in market oriented slave economies. The institutional determinists have swollen in numbers with the recent addition of some notable North American scholars. Indeed, Douglas North, William Summerhill and Barry Weingast (1998), as well as David Landes (1998), have adopted the new institutional economics to explain why Latin American performance differed so much from that of North America. The legacy of colonial institutions, weak property rights, political decentralization, and political instability are the main variables thought to affect growth. Factor endowments play a secondary role for the institutional determinists. Thus, Robinson (2000) argues that similar resource endowments, organized in different ways in terms of concentration of wealth and income, have produced very different outcomes in terms of human capital accumulation, technical change and thus economic performance.

Recently, Stanley Engerman and Kenneth Sokoloff (1997) have made an important contribution to the endowment determinist literature. They argue that "various features of the factor endowments of the three categories of New World Economies, including soils, climates, and the size or density of the native population, may have predisposed those colonies toward paths of development associated with different degrees of inequality in wealth, human capital, and political power, as well as with different potentials for economic growth. Even if, later on, institutions may ultimately affect the evolution of factor endowments, the initial conditions with respect to factor endowment had long, lingering effects" (Engerman and Sokoloff 1997: pp. 275-6). The three-economy typology offered by Engerman and Sokoloff is exactly the same as that advanced by Furtado some 30 years before, but the causality is different. Tropical crops, like sugar, are more efficiently cultivated in large estates, thus favoring property concentration. Given scarce native population in those regions, African labor was supplied through slave trade with a highly unequal income distribution emerging as an outcome. The production of grains in new settler societies, on the 
contrary, never revealed economies of scale, thus favoring a more equal society dominated by small and medium-size holders. ${ }^{6}$ The Andean and Meso American regions were characterized by substantial native populations and a privileged few who controlled the services of land, mineral resources and native labor. These mineral-based regions seem similar to tropical regions, in the sense that both generated an economic structure where large-enterprises dominated and substantial inequality resulted. Nevertheless, the explanations for the development of large estates is mainly institutional, and they have their roots in pre-Columbian and colonial experience. In any case, Engerman and Sokoloff's great contribution is to emphasize how different societies with different initial endowments yielded different distributions of income, human capital, and political power, all of which then influenced the extent of the market, the development of institutions conducive to widespread commercialization, technological change, and growth.

Victor Bulmer-Thomas (1994) also deserves an important place in this discussion. Like many others, he considers international demand to have been the dynamic force during the belle époque. Differences in performance around Latin America arose mainly from the relation between natural resource endowments, export specialization and world demand, or what has come to be called the "commodity lottery," an idea developed previously by Carlos DRaz-Alejandro (1984). Given the connection between international demand and prices, on the one hand, and natural endowments and export specialization, on the other, economic performance should have been strongly influenced by the luck of the draw in this "commodity lottery." Thus, the performance of the export sector depended in large part on demand booms and the price elasticity of demand. Economy-wide performance depended, in turn, on the relative size of the export sector and the extent to which the export boom spilled over into the domestic sector.

The "commodity lottery" is fine as far as it goes, but labor market institutions also have a

\footnotetext{
${ }^{6}$ The authors have some difficulty explaining one fact: similar endowments in the Río de la Plata and the North American prairies led to quite different land distributions and holding size (a classic theme for comparative studies,
} 
profound impact on the export supply response and on the size of any spillover to other sectors. BulmerThomas treats the whole region as labor scarce, ${ }^{7}$ and to deal with labor scarcity issues, he believes institutional explanations are essential. For him, highly concentrated natural resource ownership made it politically possible to impose a labor market solution that relied on non-market authoritarian coercion. This strategy implied technological stagnation, as there was little incentive to increase labor productivity, and it had a deleterious impact on aggregate economic performance in those parts of Latin America that used it.

\section{Different Endowments, World Markets and Different Patterns of Development}

Natural Resources. With each export specialization came market characteristics that mattered to performance. Income elasticity of demand mattered, beef offering an example of high income elasticity during the first global century, thus favoring Argentina and Uruguay. The ability of petro-chemical technologies to find ways to replace expensive natural resources with cheap synthetics mattered. Chemical fertilizers displacing guano offers a good example, thus disfavoring Peru. Market structure and monopoly power mattered. For most of the $19^{\text {th }}$ century, Brazilian coffee had a monopolistic position that allowed the state to impose export taxes and to raise prices (and revenue) by restricting supply. Similarly, Chile had a near monopoly on the mineral production of nitrates, which allowed the state to tax exports without losing its market share. In contrast, Río de la Plata was simply another entrant in the competitive world cattle market, and exporters were price-takers. Most tropical products faced competitive international markets, like cotton (Brazil and Mexico) and tobacco (Cuba). However, sugar cane offers a special tropical product case: not only did it compete with other tropical regions, but it also had to compete with the European beet root production, a situation which provoked a secular decline in the terms of trade facing northeast Brazil and Cuba.

such as that of Adelman 1994, and on Argentina see CortJ s Conde 1997).

${ }^{7}$. This view is not shared by some scholars, most notably Díaz-Alejandro (1970), Lewis (1978), and Engerman and 
Primary product export supply depended on many complementary processes. We have already talked about how the transport revolution reduced the cost of moving goods so much that relatively isolated regions suddenly found themselves integrated into the global economy. In some cases, natural resources that had previously lain idle were now exploited as the frontier extended. Northern Mexico, the Río de la Plata, the Amazonia and several other tropical regions had very low native population densities, and the expansion of the export sector obeyed the general laws of frontier economies unfolding the world around. But this "frontier case" was less common in Latin America where indigenous populations had already extensively exploited natural resources. A. Bauer (1986) lists three different Latin American landscapes where different factor endowments yielded different export-oriented economies. (1) Central México, the highlands of Central America, and the Andes were all the densely populated colonial areas where large estates, known as haciendas, co-existed with native peasant communities. In a context of illdefined property rights, hacendados steadily encroached on the land of native communities, who may have resisted but were eventually absorbed by the haciendas. The land market was active as haciendas frequently changed hands, especially near new transport routes. Lands were captured for commercial use from another source too: secular reforms converted church lands. (2) In central Chile and northern Mexico, the typical frontier pattern unfolded: haciendas expanded into lands of the vast public domain occupied only by a marginalized native population, who were displaced. (3) While the role of the haciendas was important, the countless numbers of small and medium size farms in Mexico, Central America, Colombia, Ecuador, Perú, Chile and Colombia also played a role in contributing to an elastic primary product export supply.

Diversity in export mix mattered. A well-known feature of Latin America was its highly concentrated export "portfolio." Since primary products have always been subject to wide demand and price fluctuations, the more concentrated an economy's exports, the more unstable the economy. For Latin America as a whole, the single dominant export product represented 53.6\% of total exports, while the top 
two dominant export products represented 70\% of total exports (Bulmer-Thomas 1994: Table 3.2, p. 59). These numbers are very high by world standards then and now. Still, large countries could more easily diversify, and they did. Thus, Mexico achieved a single dominant product export share in 1913 of only around $40 \%$, while that for El Salvador stood at $96 \%$. Small countries suffered greater instability as a result, and "balkanized" Latin America (see section 4) has always had small countries.

Labor. Population and thus labor force growth in Latin America between 1850 and 1930 varied enormously. The region as a whole grew by $1.5 \%$ a year (Table 2). The highlands from Chile to México recorded the lowest rates of population growth $(1.1 \%)$, the tropical lowlands held an intermediate position $(1.8 \%)$, and the more temperate lowland settler economies grew fastest $(2.8 \%)$. As a consequence, the low lands, mainly those near the Atlantic coast, increased their share in total Latin American population from 44 to $70 \%$ between 1850 and 1930 , with a corresponding contraction of the population share for the highlands. This population shift reveals the dramatic impact of $19^{\text {th }}$ and $20^{\text {th }}$ century globalization as it broke down colonial population distributions, and pulled population down to the booming export sectors supplying world markets from the lowlands and the Atlantic coast.

From central Chile to central Mexico, there existed huge concentrations of labor which were mobilized through different means in order to meet the demands of the new market orientated production. Wages were very low in the Andean highlands, and thus so too were European immigration rates. The native population of the tropical lowlands did not easily adapt to plantation work, nor was it large enough to meet the requirements of this kind of export-led production. The population of the Latin American highlands may have been closer to these tropical regions -- like Perú, Ecuador and even Yucatán -- but those native populations were not able to survive the climatic conditions of the tropical lowlands. Thus, the tropical regions eased labor scarcity by importing African slaves from the $16^{\text {th }}$ and $19^{\text {th }}$ century, replaced after suppression of the slave trade in the 1840 s and eventual abolition of slavery, some countries turned to low-wage Asian workers under labor contracts, often working under conditions of limited personal freedom. Tropical products were produced by low-wage tropical regions throughout the 
world. Table 3 shows that $47 \%$ came from low-wage tropical Latin America and $70 \%$ from the low-wage tropical world more generally. Thus, the attraction of free labor to tropical Latin America was not a viable strategy, since high labor costs would have priced them out of world product markets. In Brazil, for instance, 4 million African slaves were introduced in 1531-1855, of which 2.1 million arrived after 1781, and by the mid $19^{\text {th }}$ century more than a half of the Brazilian population was black. The labor market liberalized after the abolition of slavery in 1889 , but the consequences for low wages and inequality have been long-enduring features of Brazilian society since.

The labor supply was completely different in the temperate lowlands of the Atlantic coast. These relatively empty areas were flooded by millions of European immigrants producing temperate climate products that could now reach world markets at competitive prices. This process is analyzed in detail by Sánchez-Alonso in this volume. According to Nicolás S๔achez-Albornoz (1986: Table 3), 8.4 million immigrants arrived in Argentina, Brazil and Uruguay between 1881 and 1930, and the foreign born were a very large share of population in these countries. The structure of world markets for these kinds of temperate climate exports is also shown in Table 3. The contrast with tropical climate exports is striking: $61 \%$ of the temperate-climate world exports were supplied by high-income countries, and $26 \%$ by Latin America (mainly the southern cone). Low-wage regions played a marginal role in Latin America and the

rest of the world. As the tyranny of distance weakened, the southern cone was offered a way into the core, a process by which the frontier penetrated even more fertile lands, not less. As an outcome, wages in the region were higher than those in the European countries from whence the immigrants came. Thus, the labor market in these regions behaved quite differently than those of the tropical and highland parts of Latin America, both with respect to wage levels and with respect to their institutional features.

\section{Comparing the Outcomes}

When looking at the performance of different Latin American countries, it is useful to keep in mind that the nation-states created after independence often covered more than one region. Brazil offers 
the best example, but almost all large countries show a huge variety of climates and natural resource endowments within their own borders. Still, national level analysis offers suggestive insights.

One of the more striking facts is that economic differences among Latin America countries were greater near the end of this global era than at the beginning, as we noted in section 1. Both in terms of per capita GDP and real wages, the gap between rich and poor Latin American nations widened (see also Williamson 1999: pp. 112-19). Consistent with those forces of divergence, the settler economy (Argentina, southeast Brazil, Uruguay) share in total Latin American population rose from 11 to $30 \%$ between 1870 and 1930 (Table 2). The share of the highlands (Columbia, Mexico, Peru et al.) fell from 61 to $44 \%$ over the same period.

What about exports? Latin American export performance was impressive between 1850 and World War I, growing at an annual rate of 3.5\%. Yet, there were huge differences in the level of per capita exports between the settler, tropical and highland areas (Table 4): per capita exports in the settler countries were twice that of the tropical countries in 1912, and more than four times that of highland countries. While settler countries benefited by having large land areas and small populations, there are other likely explanations for these huge differences in per capita exports. To repeat one mentioned above, Latin American settler country exports were competing with that of developed countries, and, as marginal producers, they took a relatively high market price as given. In contrast, the price of tropical exports were set in a labor market affected by the after effects of slavery, by other forms of coercion, and by an "elastic" supply of Asian contract labor after abolition (implying a low and fixed reservation wage). Accordingly, W. Arthur Lewis (1978) argued that productivity gains were passed on to consumers abroad in the form of low and falling prices. Note, however, that while export levels differed across Latin America, their expansion up to 1912 was remarkably similar.

\section{How Independence and Conflict Caused De-Globalization}


In young, recently independent economies with low capacity to tax, few bureaucratic resources to implement efficient collection, and limited access to foreign capital markets, customs revenues are an easy-to-collect source of revenues essential to support central government expenditures on infrastructure and defense. This was certainly true of the newly-independent United States. It was even more true for a Latin America beset in the first half of the $19^{\text {th }}$ century with the collapse of the colonial fiscal system, civil wars, and violent border disputes (Prados this volume: p. 2; Coatsworth and Williamson 2002). Nor did Latin America have access to European capital markets until later in the century, ${ }^{8}$ an event that would have eased the need for tax revenues in the short run. The average share of customs duties in total revenues across eleven of the Latin American republics was 57.8 percent between 1820 and 1890 (Centeno 1997: Table 1). Customs revenues were even more important for federal governments (65.6 percent), since local and state governments who form a union typically are reluctant to give up their limited tax weapons. Furthermore, customs revenues are especially important for land-abundant economies since they do not have the population and tax-payer density to make other forms of tax collection efficient. Now add to this a huge revenue need to fight wars and we get the high United States civil war tariffs in the early 1860s and the high (and rising) tariffs in a newly independent Latin America that experienced almost continuous war and civil strife between the 1820s and the 1870 s.

David Mares (2001) reports 10 major Latin American wars between 1825 and 1879. Miguel Centeno (1997) has counted 33 major international and civil wars between 1819 and 1880. Argentina, Brazil, Chile, Cuba, Mexico, Peru and Uruguay all fought at least two major wars between independence and 1880. Only Brazil and Chile (after 1830) avoided violent military coups. Practically all of Latin America experienced episodes of massive and prolonged civil strife. In six countries, internal civil wars raged more or less continuously for decades after independence.

The universal preoccupation with national defense and internal power struggles pushed the newly independent Latin American countries toward higher revenue-maximizing tariffs. Military expenditures

\footnotetext{
${ }^{8 .}$ Indeed, there was capital flight from the young republics.
} 
quickly rose to consume over 70 and often more than 90 percent of all revenues (Centeno 1997). Weak governments, under attack from within and without, abandoned internal taxes that required an extensive and loyal bureaucracy, and concentrated instead on tax collection at a few ports and mines. The ratio of tariff revenues to imports, a proxy for protection of the import-competing sector, rose in every country for which there are data as did the customs revenues as a percentage of national government revenues.

In Brazil the ratio of import duties to imports rose from 15 percent to nearly 30 percent by the 1860s (Leff 1982), a rise that was fueled by costly wars with Uruguay, Argentina, and Paraguay as well as by frequent regional and separatist revolts, slave insurrections, and a massive social and racial upheaval in the Amazon region (Leff 1982; Cleary 1998). Between 1821 and 1867, Mexico suffered foreign invasions by Spain, the United States, and France, the secession of Texas, 13 major regional revolts, and at least 60 peasant rebellions and indigenous "caste" wars (Coatsworth 1988). Mexico's first tariff law in 1821 imposed a 25 percent ad valorem tariff on all imports. The tariff rate rose still further thereafter: it averaged 36 percent for the 1820 s as a whole, then rose to 45 percent in the 1840 s and peaked at 46 percent in the 1870s and 1880s (Beatty 2001: p. 53). Argentine tariff policies followed the Brazil/Mexico example. The independence wars (in which Argentine armies invaded Bolivia and Chile), international conflicts and blockades that followed, all served to push tariff rates upwards. Colombia offers another good example, where internal military conflicts occurred one fifth of the time between 1820 and 1879. Colombia initially adopted a "moderate" tariff regime with duties set at their colonial levels of approximately 20 percent. Tariff rates oscillated higher thereafter, rising sharply when trade revenues fell off in 1830-33 and again in 1847, each time followed by modest declines. The "Liberal" Revolution of 1849-52 raised tariff rates twice: between 1849 and 1905, ad valorem rates on cheap cotton textiles ranged from 43 to 110 percent (McGreevey 1971: p. 80).

International and internal warfare both appear to have played a major role in pushing the newly independent states toward very high tariffs designed to maximize fiscal revenues. Between 1820 and 1870, the fiscal imperative of Latin America's endemic military conflicts swamped all other 
preoccupations. We will return to this issue below when we explore the persistence of these tariff policies after 1870 when pax latina americana became the rule.

High tariffs weren't the only way that independence induced de-globalization in the young Latin American republics. Perhaps most important was the collapse "of the de facto customs union" under colonial rule (Prados, this volume: p. 2). To the extent that the colonial umbrella fostered trade and factor mobility within the region, then all of those gains were lost after independence created so many small republics, a veritable "balkanization" of Latin America. ${ }^{9}$ We simply do not know how large those losses were, just like we do not know how large the gains were to a United States after its successful revolution, independence and sustained unification. Probably far less favorable geography would have made for far less dramatic economic gains to a truly United States of Latin America, but this fact has not suppressed lively historical speculation.

It seems likely that this configuration of small national states was an enormous burden in terms of lost economies of scale and opportunities for specialization in manufacturing during the belle Jpoque period of high tariffs as well as during the years of inward looking industrialization after the 1930s.

\section{The Terms of Trade from Independence to Great Depression}

The decline in transport costs created commodity price convergence in the Atlantic economy up to the Great War, and most of Latin America was part of it. Furthermore, commodity price convergence implied terms of trade gains for all trading partners since the price of every country's exports rose in response to declining transport costs, and the price of every country's imports fell. Of course, we would like to know more about where these forces were greatest, and whether other world market events had an offsetting or reinforcing impact on any country's terms of trade. Did the tyranny of distance suffer a

\footnotetext{
${ }^{9}$ The idea of balkanization has played an important role in the literature on $19^{\text {th }}$ century Latin America. In contrast with some visionary United States of Latin America, there appeared instead many small post-independence nation-
} 
bigger defeat in the more isolated parts of Latin America or in the less isolated parts? Did the poorer regions gain less than the richer ones, or more? Which staple exports enjoyed more favorable world market forces? These questions connect closely to a very important and long debate about the secular trend in the relative price of primary products. This venerable terms of trade debate has its origin in the collapse of primary product prices during the Great Depression, but Raúl Prebisch, Hans Singer and others argued in the 1950s that the downward trend was secular (Prebisch 1950; Singer 1950). This interpretation served to fuel the policy move in Latin America in the 1950s and 1960s which had such clear autarkic outcomes. However, what these intellectual giants failed to appreciate fully is that during transport revolutions -- like that from the mid-19th century to World War I -- the terms of trade can (and did) rise for both center and periphery (Ellsworth 1956; Williamson 2002). It was not a zero-sum game. More importantly, they failed to distinguish clearly a profound Latin American turn of events in the 1890s.

Figure 2 documents the secular movements in Latin American terms of trade between 1820 and 1950. The series plots the ratio of export to import prices, the so-called net barter terms of trade. From 1870 onwards, the series is the unweighted average for eight Latin American countries (Argentina, Brazil, Chile, Columbia, Cuba, Mexico, Peru and Uruguay: Coatsworth and Williamson 2002) while it is simply the inverse of the British terms of trade before $1870 .{ }^{10}$ For Latin America as a whole, the terms of trade almost doubled between the $1820 \mathrm{~s}$ and the $1890 \mathrm{~s},{ }^{11}$ forces that must have been very favorable to income, at least in the short run. How could the poor growth performance up to the 1850 s or 1870 s possibly be

states. See, for example, Halperin Donghi (1985).

${ }^{10}$ This pre-1870 proxy understates the $19^{\text {th }}$ century rise in Latin American terms of trade to the extent that freight rates were declining on overseas routes between Britain and Latin America.

${ }^{11}$ Prados (this volume: Table 8) also collects terms of trade estimates 1811/15-1876/80 for Argentina, Brazil, Colombia, Cuba and Mexico which have recently been constructed by other authors. Trade-weighted and unweighted averages of these five countries behave almost exactly the same as our inverse of the British terms of trade between 1855 and 1880. Between 1826 and 1855, however, the Prados five record a much more modest terms of trade rise than does the British inverse. Most of that difference is explained by the collapse of the Cuban terms of trade. When Cuba is removed from the Prados sample, the resulting average terms of trade rises at a rate almost exactly like that of the British inverse. Only Argentina is documented before 1821, but its terms of trade almost doubled over those years. 
blamed on trade conditions? Instead, it certainly looks like world market forces were serving to stimulate Latin American economic performance during the first eight decades of independence.

Of course, country experience varied. While the terms of trade boomed for Argentina, Brazil and Columbia up to the late 1860 s, they rose much more modestly for Mexico, and fell dramatically for Cuba (Prados, this volume: Table 8). From the 1860s to the 1890s, the terms of trade rose for Brazil, Columbia, Cuba and the southern cone, but they fell for Mexico and Peru. After the 1890s, and long before the interwar world economic disaster, the terms of trade fell throughout Latin America. True, the collapse was less pronounced for the southern cone specializing in temperate climate primary products than it was for the others specializing in mining or tropical primary products.

In short, global market forces were, in general, good for Latin American exports over most of the $19^{\text {th }}$ century, but bad for Latin American exports over the first half of the $20^{\text {th }}$ century. What about growth? All economists agree that such terms of trade improvements must have contributed to a rise in income over the short run. We are far less certain about the long run. Indeed, Hans Singer (1950) argued that terms of trade improvements for primary product exporters might in the long run contribute to slow growth and modern development theory usually argues the same. After all, the stimulus to the primary product producing export sector is likely to cause de-industrialization or at least industrial slow down, and to the extent that industry carries modern economic growth, an aggregate growth slow down is quite possible. The jury is still out on this issue. ${ }^{12}$

\section{Why Were Tariffs So High During the Belle Époque? ${ }^{13}$}

Figure 3 plots average world tariffs before World War II, and Figure 4 plots it for various world regions. There are six plotted there -- US, European core, European periphery, European non-Latin

\footnotetext{
${ }^{12}$ While the issue is not yet resolved, recent historical evidence suggests that Singer was right (Hadass and Williamson 2001; Blattman and Hwang 2002).
} 
offshoots, Asia and Latin America, and both figures offer some big surprises. Note first the protectionist drift world-wide between 1865 and World War I, a globalization backlash if you will, registering a slow retreat from the liberal and pro-global trade positions in mid-century. The traditional literature written by European economic historians has made much of the tariff backlash on the continent after the 1870s (Kindleberger 1951; Bairoch 1989; O'Rourke and Williamson 1999). Yet, this continental move to protection is pretty minor when compared with the rise in tariff rates over the same period in Latin America, and this for a region which has been said to have exploited the pre-1914 global boom so well.

The interwar surge to world protection is, of course, better known. The first leap was in the 1920 s, which might be interpreted as a policy effort to return to the protection afforded before the war. It might also be due to postwar deflation. Inflations and deflations seem to have influenced tariff rates in the 1910s, the 1920s and some other times, a so-called specific-duty effect to which we return later in this section. The second interwar leap in tariff rates was, of course, in the 1930s, with aggressive beggar-myneighbor policies reinforced by the specific-duty effect. Except for two that had the highest pre-war tariffs, Colombia and Uruguay, tariffs rose everywhere in Latin America. Still, for most Latin American countries, tariff rates rose to levels in the late 1930s that were no higher than they were in the belle époque. $^{14}$

But note the really big fact in Figure 4. We are taught that the Latin American reluctance to go open in the late $20^{\text {th }}$ century was the product of the Great Depression and the de-linking import substitution strategies that arose to deal with it (Diaz-Alejandro 1984; Corbo 1992; Taylor 1998). Yet, by 1865 Latin America already had, with the exception of the US, by far the highest tariffs in the world. ${ }^{15}$ At

\footnotetext{
${ }^{13}$ This section draws heavily on Coatsworth and Williamson (2002).

${ }^{14}$ Of course, quotas, exchange rate management and other non-tariff policy instruments served to augment the protectionist impact of tariff barriers far more in the 1930s than in the belle époque when non-tariff barriers were far less common.

${ }^{15}$ Only two other authors in this volume devote any attention to this issue: one, Victor Bulmer-Thomas states that "tariff rates were modest" before 1914 (Bulger-Thomas "From ISI to Globalization," this volume: p. 2) and makes much of "open" export-led growth elsewhere (Bulmer-Thomas 1994); the other, Stephen Haber, notes uniformly high tariffs in Latin America and states that industry would not "have existed had it not been for tariff protection" (Haber "It Wasn't All Prebisch's Fault," this volume: p. 14 and see also pp. 15-19, 36-40). It is reasonable to
} 
the crescendo of the belle époque, Latin American tariffs were at their peak, and still way above the rest of the world.

Apparently, the famous export-led growth spurt in Latin America was consistent with enormous tariffs, even though the spurt might have been even faster without them. Latin American tariffs were still the world's highest in the 1920s, although the gap between Latin America and the rest had shrunk considerably. Oddly enough, it was in the 1930s that the rest of the world finally surpassed Latin America in securing the dubious distinction of being the most protectionist. By the 1950s, and when ISI policies were flourishing, Latin American tariffs were actually lower than those in Asia and the European periphery. ${ }^{16}$ Thus, whatever explanations are offered for the Latin American commitment to protection, we must search for its origin well before the Great Depression.

So, what was the political economy that determined Latin American tariff policy in the century before the end of the Great Depression? Before we search for answers, we need to confront the tariffgrowth debate. About thirty years ago, Paul Bairoch (1972) argued that protectionist countries grew faster in the $19^{\text {th }}$ century, not slower as every economist has found for the late $20^{\text {th }}$ century. Bairoch's pre- 1914 evidence was mainly from the European industrial core, and he simply compared growth rates in protectionist and free trade episodes. More recently, Kevin O'Rourke (2000) got the Bairoch finding again, this time using macro-econometric conditional analysis on ten countries in pre-1914 Atlantic economy.

These pioneering studies suggest that history offers a tariff-growth paradox which took the form of a regime switch somewhere between the start of World War I and the end of World War II: before the switch, high tariffs were associated with fast growth; after the switch, high tariffs were associated with slow growth. Was Latin America part of this paradox, or was it only an attribute of the industrial core? Recent work has shown that while high tariffs were associated with fast growth in the industrial core 
before World War II, they were not associated with fast growth in most of the periphery, including Latin America (Clemens and Williamson 2001; Coatsworth and Williamson 2002). Table 5 replicates the tariffgrowth paradox. In column (1) and (2), the estimated coefficient on log of the tariff rate is 0.36 for 1875 1908 and 1.45 for $1924-1934$. Thus, and in contrast with late $20^{\text {th }}$ century evidence, tariffs were associated with fast growth before 1939. But was this true world wide, or was there instead an asymmetry between industrial economies in the core and primary-producers in the periphery? Presumably, the hightariff country has to have a big domestic market, and has to be ready for industrialization, accumulation, and human capital deepening if the long run tariff-induced dynamic effects are to offset the short run gains from trade given up. Table 5 tests for asymmetry, and the hypothesis wins, especially in the preWorld War I decades for Latin America $(0.36+[-] 1.04=-0.68)$. That is, protection was associated with fast growth in the European core and their English-speaking offshoots, but it was not associated with fast growth in the periphery. Indeed, high tariffs in Latin America were associated with slow growth before World War I.

The moral of the story is while Latin American policy makers were certainly aware of the proprotectionist infant-industry argument ${ }^{17}$ offered for zollverein Germany by Frederich List and for federalist United States by Alexander Hamilton, there is absolutely no evidence after the 1860 s which would have supported those arguments for Latin America. We must look elsewhere for plausible explanations for the exceptionally high tariffs in Latin America long before the Great Depression. One of the alternative explanations involves central government revenue needs. As a signal of things to follow below, we simply note here that the causation in Table 5 could have gone the other way round. That is,

Taylor (1998: Table 2, p. 7) even when more comprehensive measures of protection and openness are employed that include non-tariff barriers.

${ }^{17}$ Bulmer-Thomas (1994: p. 140), for example, argues that late $19^{\text {th }}$ century Latin American policy makers were so aware. However, it is important to stress "late" since the use of protection specifically and consciously to foster industry does not appear to occur until the 1890s: e.g. Mexico by the early 1890s; Chile with its new tariff in 1897; Brazil in the 1890s; and Colombia in early 1900s (influenced by Mexican experience). True, Mexico saw some precocious efforts in the late 1830 s and 1840 s to promote modern industry, but these lapsed with renewed local and international warfare. So, the qualitative evidence suggests that domestic industry protection becomes a motivation for Latin American tariffs only in the late $19^{\text {th }}$ century. 
Latin American countries achieving rapid GDP per capita growth would also have undergone faster growth in imports and other parts of the tax base, thus reducing the need for high tariff rates. And countries suffering slow growth would have had to keep high tariff rates to ensure adequate revenues.

So, what explains those high Latin American tariffs in the belle époque?

Revenue Targets and Optimal Tariffs for Revenue Maximization. As Douglas Irwin (1997: pp. 8- 12) has pointed out for the United States, and as Bulmer-Thomas (1994: p. 141) has pointed out for Latin America, the revenue-maximizing tariff hinges crucially on the price elasticity of import demand. Tariff revenue can be expressed as $\mathrm{R}=\mathrm{tpM}$ where $\mathrm{R}$ is revenue, $\mathrm{t}$ is the average ad valorem tariff rate, $\mathrm{p}$ is the average price of imports and $\mathrm{M}$ is the volume of imports. Assuming for the moment that the typical Latin American country took its import and export prices as given, then a little math lets us restate this expression as the change in tariff revenues $\mathrm{dR} / \mathrm{dt}=\mathrm{pM}+(\mathrm{tp}) \mathrm{dM} / \mathrm{dt}$. The revenue-maximizing tariff rate, $t^{*}$, is found by setting $d R / d t=0$ (the peak of some Laffer Curve), in which case $t^{*}=-1 /(1+\eta)$, where $\eta$ is the price elasticity of demand for imports. Irwin (1997: p. 14) estimates the price elasticity to have been about -2.6 for the US between 1869 and 1913. If the price elasticity for Latin America was similar, say about -3 , then the average tariff in Latin America would have been very high indeed, 50 percent.

Suppose instead that some Latin American government during the belle époque -- riding on an export boom -- had in mind some target revenue share in GDP $(\mathrm{R} / \mathrm{Y}=\mathrm{r})$ and could not rely on foreign capital inflows to balance the current account (so $\mathrm{pM}=\mathrm{X}$ ), then $\mathrm{r}=\mathrm{tpM} / \mathrm{Y}=\mathrm{tX} / \mathrm{Y}$. Clearly, if foreign exchange earnings from exports (and thus spent on imports) were booming (an event which could even be caused by a terms of trade boom, denoted here by a fall in $\mathrm{p}$, the relative price of imports), the target revenue share could have been achieved at lower tariff rates. The bigger the export boom and the higher the resulting export share $(\mathrm{X} / \mathrm{Y})$, the lower the tariff rate.

So, did Latin American governments act as if they were meeting revenue targets? Holding everything else constant, did they lower tariff rates during world primary product booms when export 
shares were high and rising, and did they raise them during world primary product slumps? They did indeed (Coastworth and Williamson 2002). Furthermore, those countries which had better access to world capital markets had less short run needs for tariff revenues, and had lower tariffs.

The Specific-Duty Effect. It has been argued that inflations and deflations have had a powerful influence on average tariff rates in the past. Import duties were typically specific until modern times, quoted as pesos per bale, yen per yard, or dollars per bag. Under specific duties, abrupt changes in price levels would change import values in the denominator, but not the legislated duty in the numerator, thus producing big equivalent ad valorem or percentage rate changes. Thus, tariff rates fell sharply during the wartime inflations between 1914 and 1919 and 1939 and 1947. Part of the rise in tariffs immediately after World War I was also due to post-war deflation and the partial attainment of prewar price levels. The price deflation after 1929 was even more spectacular, and it too served to raise tariff rates at least on duties that were still specific (import values now declining).

This specific-duty effect has been noted for pre-revolutionary Mexico (Marquez 2002: p. 307), belle époque Uruguay (Bértola 2000: Chps. 6 and 7), and now we know it holds for Latin America as a whole (Coatsworth and Williamson 2002). Still, it cannot explain those relatively high and rising tariff rates in Latin America before World War I.

Strategic Trade Policy, the Terms of Trade and Tariffs. A well-developed theoretical literature on strategic trade policy predicts that nations have an incentive to inflate their own terms of trade with high tariffs, encouraging competitive tariff setting between trading partners. It turns out that most of Latin America faced far higher tariffs than anyone else since they traded with heavily protected countries like the US and each other. So, did this "hostile" policy environment abroad trigger a like response at home? The answer is a definite yes, although this was far more important in the interwar years than the belle époque.

De-Industrialization Fears. If Latin American policy makers feared that globalization would induce local de-industrialization, they would have paid close attention to the competitive position of 
manufacturing at home relative to that abroad. The best indicator of foreign manufacturing's competitiveness would be its ability to drive down the relative price of manufactures in world markets through productivity advance. Thus, de-industrialization fears ought to have been manifested by a rise in Latin American tariff rates when the relative price of manufactures fell in world markets. Figure 2 suggests that there was much to fear before the mid-1890s since, relative to the price of Latin America's key primary-product exports, the price of manufactures fell dramatically in world markets. Another way of saying the same thing is that Latin America enjoyed a big improvement in its terms of trade: the price of Latin American primary products rose in world markets relative to manufactures. After 1895, the deindustrialization story changes and since there was now nothing to fear: the terms of trade fell and the relative price of manufactures rose. The timing is puzzling since the qualitative literature often identifies a switch about that time in the motivation behind belle époque tariffs from revenue to industrial-protection goals. If de-industrialization fears were all there was to it, we should have seen a switch away from industrial-protection goals after the 1890s (there was less need to protect), not towards them.

The Tariff-Transport Cost Trade Off. Whatever the arguments for protection of manufacturing in the periphery, high transport costs on imports from one's trading partner are just as effective as high tariffs. And when transport costs fall dramatically, the winds of competition thus created give powerful incentive to import competing industries to lobby for more protection. Thus, there must have been plenty of incentive for manufacturing interests in the periphery to lobby for protection as the natural barriers afforded by transport costs melted away in the $19^{\text {th }}$ century.

There are two reasons to doubt that the tariff-transport cost trade-off prevailed with the same power in Latin America as in Europe during its "grain invasion." First, and as we noted above, while overseas freight rates along the northward routes carrying primary products to Europe from the coasts of Latin America followed world trends by collapsing after the 1840s, they fell much less along the southward leg carrying manufactures to Latin America (Stemmer 1989: p. 24). Second, transport costs into the Latin American interior were much more important protective barriers for local manufacturers 
than were overseas transport costs. Thus, transport revolutions along the sea lanes connecting Latin America to Europe had far less to do with tariff responses than did investment in railroads at home (Bértola 2000: chp. 4; Coatsworth and Williamson 2002). Where and when railroads integrated the Latin American interior with the world economy, we see a protectionist response, apparently as import competing industries successfully lobbied for protection from these new winds of competition.

The Stolper-Samuelson Theorem and Latin American Capitalists. Even if the motivation for Latin American tariffs lay with revenues or some other source, they were still protective. After all, tariffs served to twist relative prices in favor of import competing sectors, thus suppressing growth in the export sector and stimulating urban-based manufacturing. But was protection of manufacturing a central motivation for high tariffs in Latin America, especially after the export-led boom filled treasuries with new revenues that reduced debt service to manageable dimensions?

Ronald Rogowski (1989) has used the Stolper-Samuelson theorem to search for an alternative political economy explanation for those extraordinarily high tariffs during the belle époque. Though their economies certainly varied in labor-scarcity, every Latin American country faced relative capital scarcity and relative natural resource abundance. Thus, according to Stolper-Samuelson thinking, Latin American capitalists should have been looking to form protectionist coalitions as soon as belle époque peace and growth began to threaten them with freer trade. In most cases, they did not have to look far, either because they managed to dominate oligarchic regimes that excluded other interests, or because they readily found coalition partners willing to help, or both. Capitalists did not, however, look to labor for help. After all, most Latin American countries limited the franchise to a small minority of adult men until well into the $20^{\text {th }}$ century. Literacy and wealth requirements excluded most potential voters in virtually every country (Engerman and Sokoloff 2001). Of course, non-voters found other ways to express their interests, but, with few exceptions, restrictions on the adult male franchise did not fall until after 1930 when the votes of scarce labor began to count, just in time for the populists. 
Growth, peace and political stability in the late $19^{\text {th }}$ century tended, therefore, to produce oligarchic governments in which urban capitalists -- linked to external trade and finance -- played a dominant role. In countries that specialized in exporting agricultural products, free-trading landowners formed the second dominant part of the governing oligarchy. Here, the standard view is that something much closer to free trade prevailed where domestic landowners must have dominated politics. Rogowski has argued, for example, that in contrast to the United States, Canada, New Zealand and other "frontier" regions, landowners won in Latin America (Rogowski 1989: p. 47). Rogowski appears to have gotten both the politics and tariff policy outcome wrong. Four Latin American agricultural exporters -Argentina, Brazil, Colombia, and Uruguay -- expanded export production in the late $19^{\text {th }}$ century by putting new lands to the plough or modernizing and extending pastoral production (cattle and wool) for export. In backward economies with high land-labor ratios, Rogowski argued that expanding trade should produce assertive free trading landed interests pitted against defensive populist alliances of capitalists and workers. In all four of these frontier nations, however, tariff rates were substantially higher than in other world regions. Either Latin America's export producing landowners had less political clout or weaker free trade preferences than this account suggests. Or both.

Free-trading mineral export interests usually had less direct leverage in governmental decision making. In the case of the three mineral exporters (Mexico, Chile, and Peru), one might have expected mining interests to have allied themselves with powerful regional agricultural interests to lobby against protection. Yet, this did not happen. As we have seen, nor were agricultural exporters very effective in forging free trade coalitions with other interests. Perhaps one reason why it didn't happen is that free traders might have had their enthusiasm tempered by the knowledge that government revenue had to be raised somehow, and one obvious alternative to the tariff -- a tax on land -- was abhorrent to the powerful latifundistas (Bulmer-Thomas 1994: p. 140). 
In short, urban capitalists secured explicitly protectionist tariffs for existing and new industries beginning in the 1890 s. They did so against weak opposition and in close collaboration with modernizing political elites. They did not yet need the populist coalitions that emerged in the interwar decades.

Policy Packages and Real Exchange Rate Trade-Offs. Few policies are decided in isolation from others. Indeed, there were other ways that Latin American governments could have improved the competitive position of import-competing industries, if such protection was their goal, and they explored many of these alternatives in the 1930s and in the ISI years that followed. One powerful tool was manipulating the real exchange rate, something at which Mexico was adept before 1900 (Márquez 2002: see also Bulmer-Thomas 1994: chps. 4 and 5). When Latin American governments chose to go on the gold standard or to peg to a core currency, they got in return more stable real exchange rates, and perhaps good advertising for foreign capital. However, they gave up protection via real exchange rate manipulation. The historical facts are consistent with the theory: countries that went on the gold standard raised tariffs (Coatsworth and Williamson 2002).

Market Size and Density: Big countries, as measured by population size, had lower tariff rates, a result consistent with the view that big domestic markets were more friendly to foreign imports since local firms would have found it easier to carve out regional and product niches, or with the view that large countries are forced to develop alternative revenue sources since they have lower foreign trade shares in income, or both. Producers in countries with relatively small domestic markets -- like Chile, Cuba and Uruguay -- would have found it harder to hide in spatial niches, thus lobbying for higher tariffs, and governments would have favored this lobbying since tariffs were such a dominant revenue source given high foreign trade shares.

This section started by pointing out that tariffs in Latin America were far higher than anywhere else in the world from the 1860 s to World War I, long before the Great Depression. Indeed, tariff rates in Latin America were even on the rise in the decades before 1914. High tariffs should have favored the domestic import competing industry, namely, manufacturing. It also should have taken some of the steam 
out of the export-led boom during the belle époque. But was it protection and de-industrialization fears that motivated those high tariffs? Apparently not. Tariffs in Latin America were viewed mainly as a revenue source, as a strategic policy response to trading partners tariffs, as a redistributive device for special interests, and as a consequence of other political economy struggles. But revenue needs were the central motivation behind those exceptionally high tariffs. While all young countries have revenue needs, they were especially pressing in Latin America where levels of military conflict were exceptional up to the 1870s when the rest of the world was enjoying pax britannica. Exceptionally high levels of pre-1870 violence led to exceptionally high tariff rates.

\section{Export-Led Growth and Industrialization}

\section{Advancing in Circles: Industry and Export-Led Growth}

By the 1960s and 1970s, regional analysts were obsessed by Latin American underdevelopment in general and the crisis of the ISI model in particular. While colonial heritage and $19^{\text {th }}$ century nationbuilding were always viewed as central underlying causes of modern underdevelopment, studies of trade

policy almost without exception started with the 1930s and the ISI model. Typically, industrialization was considered a post-Great Depression phenomena, evolving as a policy-induced reaction to the interwar crisis of the export-led growth model based on primary product exports and industrial imports (United Nations, ECLA 1966).

A reaction set in during the 1970 s when historians began to stress the importance of what came to be labeled "early industry." Many studies explored the features of early industrial growth, dated in some cases from World War I, in others from the 1880s or even earlier, as exemplified by Aurora Gómez's contribution to this volume. By industry, we are not talking about handicraft production embedded in the agrarian-colonial economy; nor are we talking about primary product processing, activities that added 
very little value to these primary products before they were exported. We are talking about large industrial enterprises with an advanced division of labor and considerable capital-intensity.

Once it had been clearly established that modern industry had existed side by side with export-led growth long before the Great Depression, different scholars offered competing explanations for it. Some thought industrial growth was not possible if export-led growth was truly successful. Thus, the explanation for industrial growth had to be found in various constraints on export-led growth that would have allowed industry to thrive along side it. One such constraint was protection. As we noted in the previous section, a central point of controversy is whether high tariffs emerged to generate revenues for the state, or whether they were consciously oriented towards the promotion of industrial growth. This discussion was related to another: were industrial capitalists opposed to export interests and their policies (following some Stolper-Samuelson predictions), or was industrial investment seen as harmonious with export-led growth (Lewis 1986)? Thus, while some scholars stress the protection afforded by tariffs and geographic isolation, others view early industrial growth in terms of domestic forces. The later includes the expansion of local demand, access to cheap raw materials and labor, better output prices and favorable exchange rates.

Before we can assess this debate, we need to define terms. If by industrialization we mean a process by which manufacturing output grows faster than that of other sectors for a long enough time to significantly alter output mix, then it appears that industrialization was never achieved in Latin America prior to the 1930s. To take the most compelling example, Argentine GDP grew at an annual rate of 5.5\% between 1875 and 1930, while industry grew at a rate only slightly faster, $6.0 \%$ (Cortés Conde and Harriague 1993). If we assume that industry represented $12 \%$ of GDP in 1880 , its share, according to these growth rates, should have risen ever so modestly to $15.2 \%$ in 1930 . In contrast, between 1935 and 1960 the industrial share in Argentina increased from 15 to 21\% (V \&quez Presedo 1988). Uruguay recorded a similar performance between 1870 and 1930 (Bértola, et.al.1998), while the industrial share increased from 11 to $23 \%$ between 1930 and 1960 (Bértola 1990). This important part of the southern 
cone did not undergo significant industrialization before 1930, and it seems unlikely that other Latin American countries underwent a more dramatic industrialization experience. Indeed, manufacturing output shares around World War I were considerably lower elsewhere in Latin America than in Argentina (Brazil 1920, 12.2\%; Colombia 1925, 6.7\%; Mexico 1910, 12.3\%; all from Bulmer-Thomas 1994: Table $5.3, \mathrm{p} .137)$.

Did this result arise due to some fault with Latin American industry and its industrialists? Maybe. But it could also have been fostered by what we have come to call the Dutch disease. After all, the relative price of manufactures facing Latin America fell dramatically across the century before the 1890s (Figure 2), a force that gave enormous incentive to primary product expansion at the expense of importcompeting manufactures. Those trends ceased late in the century after which the relative price of manufactures rose just as dramatically (e.g. Latin America's terms of trade deteriorated). Did this switch in world price trends provoke industrialization throughout Latin America after the 1890 s, or did the region have to wait until the 1930s and the introduction of ISI policy?

\section{The Limits of Export-Led and Industry-Led Growth}

Between 1870 and 1913, the more advanced regions of the world experienced rising industrial shares and associated urbanization. Even world trade was increasingly industrial: while trade in primary

products grew more than did that of industrial products in the early $19^{\text {th }}$ century, industrial trade caught up late in the century and forged ahead in the early 1900s. Yet, Latin American exports remained primary products to an overwhelming extent. Were there limits to export-led growth?

First, World demand and prices set one limit. As we have seen, the relative price trend favoring primary products in Latin America turned around after the 1890s, a switch that must have been due at least partly to a weakened demand for primary products relative to manufactures. However, demand limits cannot be completely isolated from supply limits. If some "structural; limitation" made it difficult 
for a country to shift resources out of traditional exports into sectors with fast-growing product demand, its capacity to grow will be diminished.

Second, was Latin America more or less competitive in "dynamic" products, like those in manufacturing? Were there limits to industrial growth in Latin America? One limit to Latin American industrialization was the domestic market. For most countries in Latin America, domestic markets were far too small, a clear disadvantage resulting from the "balkanization" of the region two centuries earlier at independence. For example, around the 1850s, the four biggest Latin American countries (Brazil, Columbia, Mexico and Peru) had on average populations one-sixth the size of the four biggest west European countries (France, Germany, Italy, and the United Kingdom). Alternatively, the next five middle-sized Latin American countries (Argentina, Bolivia, Chile, Cuba and Venezuela) were on average less than one-third the size of the average mid-sized western European country (Belgium, Netherlands, Portugal, Sweden and Switzerland). Small populations made for small markets, but poverty, low per capita income and regional fragmentation made those domestic markets even smaller. In addition, income was unevenly distributed at the start, further shrinking the domestic market for mass-produced goods. And, as we will show in the next section, inequality grew even worse during the belle époque as Latin America responded to world demand with export-led growth. None of these factors yielded the kind of local market in which domestic industry could exploit scale economies and improve productivity until it could go it alone in home markets without tariffs, let alone trying to penetrate foreign markets.

During the $19^{\text {th }}$ century, industrial growth was mainly based on relatively simple technologies, and by 1910 these had spread all over the world. Some Latin American industries did grow during this globalization process, but they did so only behind high tariff walls. Textiles was the leading sector everywhere around the world, but in 1910 Latin America - as illustrated by Mexico - was simply not competitive. As Gregory Clark (1987) has shown, compared with England, spindles in Mexico were half again more expensive, and coal was four times more expensive. Yet, wages were only half of those in England (Clark 1987: Table 1, p. 146). Was that cheap-labor advantage enough to give Mexico a 
competitive edge in home and even world markets? Apparently not, since Mexican labor was so inefficient that labor costs per unit of output were higher than in England. Thus, only tariffs insured the survival of the textile industry in Mexico, and what was true of Mexican textiles was probably true of most industries in Latin America (Haber, this volume: p. 14). And, of course, things got even worse over time as tariffs reduced competition and muted the process of innovation.

The timing here is important: Latin America was simply unprepared for the petro-chemical industrial wave - the late $19^{\text {th }}$ century "second" industrial revolution -- which embodied more complex technologies, larger scale and higher skill requirements. International competition in world manufacturing markets depended increasingly on skills, and Latin America, already having lost the battle over old industrial technologies, was hardly well positioned to deal with this new competition. Even in Argentina and Uruguay, the richest part of Latin America, school enrollment rates in the 1910s were very low by North American and European standards: only 42.2 and 33.6\% of school-aged children attended school in Argentina and Uruguay, respectively, not to mention Brazil with only $12.3 \%$. Overall school attendance in Argentina, Uruguay and Brazil were 52, 42 and 18\%, respectively, of that in France, Germany, the UK and the US combined (Bértola and Bertoni 1998: Statistical Appendix; see also Bértola 2000: Chapter 4). Illiteracy rates made Latin America look even worse. In 1910, 62\% of Latin America was illiterate, when the figures for North America were about 8 or 9\% (Astorga and Fitzgerald 1998b: Statistical Appendix).

Latin America had to deal with the second industrial revolution before it had undergone the first.

\section{Globalization and Inequality}

Looking backwards while writing around World War I, two Swedish economists -- Eli Heckscher and Bertil Ohlin -- argued that the integration of global commodity markets would lead to convergence of international factor prices, as countries everywhere expanded the production and export of commodities which used their abundant (and cheap) factor intensively. The historical evidence for the southern cone -- 
trends in the ratio of wages to land rents or land values from Argentina (O'Rourke, Taylor and Williamson 1996) and Uruguay (Bértola et al. 1999) - seems to be consistent with the predictions of Heckscher and Ohlin. They appear in Table 6.

The trade boom during the half century before World War I led to falling wage-rental ratios in relatively land-abundant southern cone, just as Heckscher and Ohlin would have predicted. As the exports of land-intensive products boomed, so did the demand for land and thus rents and land values. As the imports of labor-intensive manufactured products also boomed, the demand for labor fell, at least relative to land, and thus so did the wage-rental or the wage-land-value ratio. Taking 1913 as the base, the wagerental (or the wage-land-value) ratio plunged from about 6.9 to about 0.6 between 1880-1884 and 19151919 in Argentina, and from 11.1 to 1.2 between 1870-1874 and 1915-1919 in Uruguay. Alternatively, the ratio of land rents to wages soared by about ten times over these four or five decades. This is a huge change in the relative scarcity of land and labor, with powerful inequality implications. As it turns out, these trends were typical everywhere in the land-abundant periphery which, like Australia and North America (O'Rourke, Taylor and Williamson 1996) or like Thailand and the Punjab (Williamson 2002), were exporting to the booming industrial core. Exactly the opposite trends were taking place in Europe, especially in those parts of Europe which stuck to their free trade guns: i.e., wage-rental ratios soared in Britain, Ireland and Scandinavia. To the extent that land holdings were highly concentrated at the top, these trends clearly implied falling inequality in Europe, but rising inequality in the southern cone. Furthermore, when the world economy fell apart after World War I, the steep decline in the wage-rental ratio stopped in Argentina and Uruguay and actually began to rise in the 1930s (Table 6). Presumably, inequality trends reversed as well.

So much for factor demand and globalization. What about factor supply? Sir Arthur Lewis (1954) used his famous labor surplus model to show how early industrialization could create inequality. According to his model, the worker fails to share in GDP per capita growth since elastic labor supplies keep wages and living standards stable. Lewis is quiet about what happens to land rents, but the classical 
model from which his was derived clearly predicted a rise. Carlos Diaz-Aljandro (1970), on Argentina, and Nathaniel Leff $(1972 ; 1992)$, on Brazil, have both used the labor surplus model to predict stable real wages in Latin America, appealing to the migration of surplus labor from the Mediterranean. While the thesis that these parts of Latin America had more elastic labor supplies than the English-speaking new world has been rejected (Taylor 1994; Hatton and Williamson 1998: pp. 42-6), they did have higher rates of immigration and labor force growth than elsewhere in Latin America. This process of intensification may have suppressed real wage growth relative to other factor prices like land rents. After all, labor supplies were more elastic than land: land/labor ratios fell in the southern cone in spite of new land settlement and expanding frontiers. Meanwhile, rising export prices raised land rents and land values. Note also that the fact that mass migrations into Argentina and Uruguay dropped off sharply after World War I ( $\mathrm{S} \varangle$ chez-Alonso, this volume) is consistent with the turn-around in the wage-rental ratio drift in Table 6.

It follows that the Heckscher-Ohlin globalization model and the Lewis labor-surplus model both predict falling wage-rental ratios and rising inequality in the export-led southern cone prior to World War I, and the opposite thereafter. Regardless of which thesis explains southern cone history best, we need to know whether this experience was ubiquitous across Latin America.

Complete income distributions at various benchmarks from Independence to World War II are unavailable for any Latin American country, including Argentina and Uruguay. Still, our interest here is factor prices: unskilled wages, land rents, the premium on skills, and the return to capital. How did the typical unskilled worker, landless laborer or small scale farmer near the bottom of the distribution do relative to the typical landowner or capitalist near the top, or even relative to the typical skilled blue collar worker or educated white collar employee near the middle?

There are two kinds of evidence available to document inequality trends in belle époque and interwar Latin America: trends in the wage-rental ratio, which we have already explored, but, sad to say, are limited to Argentina and Uruguay; and trends in the ratio of the unskilled wage to GDP per capita, 
which we have not yet explored, and which are available for seven Latin American regions between 1870 and 1940.

Table 7 reports trends in the ratio of the unskilled worker's wage (w) to the returns on all factors per person as measured by Angus Maddison's (1995) and Pablo Astorga and Valpy FitzGerald's (1998a) estimates of GDP per capita (y). These trends in w/y should approximate changes in the economic distance between the working poor near the bottom of the distribution and the average citizen in the middle of the distribution. Argentina, Mexico and Uruguay document the longest time series, and Table 7 shows that all three underwent a long, steep decline in w/y before it flattened out (Mexico) or even rose (Argentina and Uruguay) after World War I. The turning point for all three is 1915-1919, a result consistent with wage-rental ratio trends in Table 6 documented for just Argentina and Uruguay. Although its time series is shorter, Cuba seemed to obey the same laws of motion and the same turning point. Colombia's time series is even shorter than Cuba's, so we do not know whether 1910-1914 was a turning point for Colombia or not. The pre-World War I evidence in Table 7 is consistent with either the Heckscher-Ohlin or the Lewis explanations.

But what about after World War I? As the world adopted autarkic policies and as Latin America faced a deterioration in its terms of trade across the 1920s and 1930s, one would have thought that these de-globalizing forces would have had egalitarian effects. In some cases, that is exactly what we observe in Table 7 -- a rise in w/y. In Brazil and Mexico, we do not. A continued secular decline in w/y might be expected of Brazil, a huge country with severe regional inequalities, a relatively small trade share in income, and a large domestic labor reservoir with roots in the former slave economy. Mexico may share many of the features of the Brazilian economy, but it is complicated by the revolution and the reforms that followed.

The regions of new settlement documented in Table 7, Argentina and Uruguay, certainly offer the most compelling case for the globalization and inequality connection. These trends of rising inequality during the first great globalization boom and falling inequality during the interwar years of de- 
globalization are consistent with booms and busts in mass immigration and trade, but we don't know which one mattered most. To the extent that the pre-war trade boom (and interwar bust) accounted for the pre-war immigration boom (and interwar bust), perhaps we don't care which mattered most since they would have their origin in the same global forces.

Why did the real wage lag behind GDP per capita in so much of Latin America during the first great globalization boom? Is this evidence of some weaker version of the Lewis model, one without a constant real wage but with sluggish real wage growth and modest trickling down? Is it evidence supporting the factor-price convergence theorem? Or is it both? And why the common turning point for economies with such different attributes? Since it seems unlikely that such dissimilar economies could share the same turning point if it was domestic forces at work, the most likely explanation probably lies with world markets. These countries were more likely to have shared similar price shocks which produced similar inequality trends.

Real wages lagged behind GDP per capita growth everywhere in Latin America up to World War I. Real wages outstripped GDP per capita growth in many parts of Latin America thereafter. We interpret these trends as rising inequality during the first great globalization boom and falling inequality during the interwar years of de-globalization. The correlation was probably causal.

\section{An Agenda for the Future}

In recent decades, we have learned a lot about the impact of globalization forces on pre-1940 Latin America, but much more remains to be done. This survey has raised five major questions that should keep scholars busy over the next few decades.

First: Did export-led growth suppress industrialization enough to account for the fact that while the belle époque achieved a half century of "fairly fast" growth, it did not achieve any significant catching up on the industrial leaders? 
Second: Industrialization in Latin America before 1930 was modest at best, but it was fast afterwards. How much of that change in performance was due to the change in policy - from pro-global to anti-global, and how much of it was due to the dramatic change in the terms of trade drift - from steeply rising primary product prices (relative to manufactured goods) before the 1890s to steeply falling relative primary product prices after the 1890s? These two forces reinforced each other, but how much due to world markets and how much due to policy?

Third: Independence early in the $19^{\text {th }}$ century produced market balkanization and anti-global policies that persisted for a half century or longer. Indeed, they still persist today. How important were those effects? How much did Latin America lose from moving away from a common market with a common currency (while the United States gained by embracing it)? If the impact was big, can Latin America get it back, two centuries later, by modern regional unification schemes?

Fourth: When and where does the motive for tariffs switch from revenue needs to industrial policy goals, and, more importantly, why? The most dramatic changes in tariff policy also seem to have been driven by strategic tariff motivation, a motive apparently absent before World War I while a dominate force afterwards. Furthermore, exactly how has Latin American trade policy interacted with the increasing availability of domestic tax instruments, with changing immigration policy, and with changing policies towards foreign capital?

Fifth: Latin America today is one of the most unequal regions in the world. How much of the unusually high inequality of income and wealth in Latin America today was driven to those levels at the outset of and during the belle époque? How much of this Latin American exceptionalism has colonial roots? We know that both mattered, but by putting more empirical teeth into the answers historians might make an important contribution to the ongoing debate about who gains and who loses from globalization. 


\section{References}

ACEMOGLU, D.; JOHNSON, S.; and J. A. ROBINSON (2001), "The Colonial Origins of Comparative

Development: An Empirical Investigation," American Economic Review (December): 1369-401.

ADELMAN, J. (1994), Frontier Development. Land, Labour and Capital in the Wheatlands of Argentina and Canada 1890-1914 (Oxford: Clarendon Press).

ASTORGA, P. and V. FITZGERALD (1998a), "The Standard of Living in Latin America During the Twentieth Century," Development Studies Working Paper N. 117, Queen Elizabeth House, St. Antony's College, University of Oxford (May).

--- (1998b), "Statistical Appendix." In Progress, Poverty and Exclusion. An Economic History of Latin America in the Twentieth Century ed. by R. M. Thorp (Washington, D.C.: Inter-American Development Bank).

BAIROCH, P. (1972), "Free Trade and European Economic Development in the $19^{\text {th }}$ Century," European Economic Review 3 (November): 211-45.

--- (1989), "European Trade Policy, 1815-1914." In The Cambridge Economic History of Europe:

Volume III, ed. by P. Mathias and S. Pollard (Cambridge: Cambridge University Press).

BAUER, A. (1986), "Rural Spanish America, 1870-1930." In The Cambridge History of Latin America:

Volume IV: c 1870 to 1930, ed. by L. Bethell (Cambridge: Cambridge University Press).

BEATTY, E. (2001), Institutions and Investment: The Political Basis of Industrialization Before 1911

(Stanford: Stanford University Press).

BÉRTOLA, L. (1990), The Manufacturing Industry of Uruguay, 1913-1961: a sectoral approach to growth,

fluctuations and crisis (Stockholm: Institute of Latin American Studies of Stockholm University, Monograph No 20). 
BÉRTOLA, L. (2000), Ensayos de Historia Económica: Uruguay y la región en la economia mundial 1870-1990 (Montevideo: Ediciones Trilce).

BÉRTOLA, L and R. BERTONI (1998), "Educación y aprendizaje en escenarios de convergencia y divergencia,” Documento de Trabajo \#46, Unidad Multidisciplinaria, Facultad de Ciencias Sociales, Universidad de la República.

BÉRTOLA, L.; L. CALICCHIO; M. CAMOU; and G. PORCILE (1999), "Southern Cone Real Wages Compared: A Purchasing Power Parity Approach to Convergence and Divergence Trends, 1870-1996," Documento de Trabajo \#44, Unidad Multidisciplinaria, Facultad de Ciencias Sociales, Universidad de la Republica (February).

BÉRTOLA, L, L. CALICCHIO; M. CAMOU; and L. RIVERO (1998), "El PBI uruguayo 1870-1936 y otras estimaciones," Facultad de Ciencias Sociales, Universidad de la Republica.

BLAINEY, G. (1966), The Tyranny of Distance: How Distance Shaped Australia's History (Melbourne: Macmillan, revised 1982 ed.).

BLATTMAN, C. and J. HWANG (2002), "The Terms of Trade Debate Revisited - Again," unpublished paper, Department of Economics, Harvard University (September).

BRADING, C. W. (1969), "Un analisis comparativo del costo de la vida en diversas capitales de hispanoamerica," Boletin Historico de la Fundacion John Boulton 20 (March): 229-63.

BULMER-THOMAS, V. (1994), The Economic History of Latin America Since Independence

(Cambridge: Cambridge University Press).

CARDOSO, C. F. S. and H. PÉREZ BRIGNOLI (1979), Historia Económica de América Latina, I-II, (Barcelona).

CARDOSO, F. H. and E. FALETTO (1979), Dependency and Development in Latin America (Berkeley, CA.: University of California Press).

CENTANO, M. A. (1997), "Blood and Debt: War and Taxation in Nineteenth-Century Latin America," American Journal of Sociology 102 (May): 1565-605. 
CLARK, G. (1987), "Why Isn't the Whole World Developed? Lessons from the Cotton Mills," Journal of Economic History 47 (March): 141-73.

CLEARY, D. (1998), "'Lost Altogether to the Civilized World': Race and the Cabanagem in Northern Brazil, 1750-1850," Comparative Studies in Society and History 401 (January): 109-35.

CLEMENS, M. A. and J. G. WILLIAMSON (2001), “A Tariff-Growth Paradox? Protection's Impact the World Around 1875-1997," NBER Working Paper 8459, National Bureau of Economic Research, Cambridge, Mass. (September).

COATSWORTH, J. H. (1981), Growth Against Development -- The Economic Impact of Railroads in Porfirian Mexico (Dekalb, Ill.: Northern Illinois University Press).

--- 1988. "Patterns of Rural Rebellion in Latin America: Mexico in Comparative Perspective." In Riot, Rebellion, and Revolution: Rural Social Conflict in Mexico, ed. by F. Katz (Princeton: Princeton University Press).

COATSWORTH, J. and J. G. WILLIAMSON (2002), "The Roots of Latin American Protectionism: Looking Before the Great Depression," NBER Working Paper 8999, National Bureau of Economic Research, Cambridge, Mass. (June).

CORBO, V. (1992), "Development Strategies and Policies in Latin America: A Historical Perspective," International Center for Economic Growth, Occasional Paper No. 22 (April): 16-48.

CORTI S CONDE, R. (1997), La economia argentina en el largo plazo: ensayos de historia econ\mica de

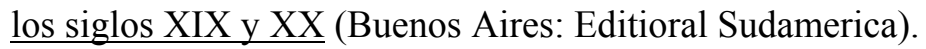

CORTÉS CONDE, R. and M. HARRIAGUE (1993), "Estimaciones sobre el PBI en Argentina 18741935", Documento de Trabajo \# 3, Universidad de San Andrés, Buenos Aires.

CUEVA, A. (1977), El Desarrollo del Capitalismo en América Latina, 2ª ed. (México).

DIAZ-ALEJANDRO, C. F. (1970), Essays on the Economic History of the Argentine Republic (New Haven, Conn.: Yale University Press). 
--- (1984), "Latin America in the 1930s." In Latin America in the 1930s, ed. by R. Thorpe (New York: Macmillan).

ELLSWORTH, P. T. (1956), "The Terms of Trade between Primary Producing and Industrial Countries," Inter-American Economic Affairs 10 (Summer): 47-65.

ENGERMAN, S. L. and K. L. SOKOLOFF (1997), "Factor Endowments, Institutions, and Differential Paths of Growth Among New World Economies: A View from Economic Historians of the United States." In How Latin America Fell Behind, ed. by S. Haber (Stanford, Cal.: Stanford University Press). --- (2001), "The Evolution of Suffrage in the New World: A Preliminary Examination." Paper presented to the 2001 Cliometrics Conference, Tuscon, Arizona (May 18-20).

FURTADO, C. (1974), La Economía Latinoamericana desde la Conquista Ibérica hasta la Revolución Cubana (México).

GALLUP, J. and J. D. SACHS (with A. D. MELLINGER) (1999),"Geography and Economic Development." In Annual World Bank Conference on Development Economics, 1998, ed.by B. Pleskovic and J. E. Stiglitz (Washington, D. C.: World Bank).

GLADE, W. (1986), "Latin America and the International Economy, 1870-1914." In The Cambridge History of Latin America: Volume IV: c 1870 to 1930 ed. by L. Bethell (Cambridge: Cambridge University Press).

HADASS, Y. and J. G. WILLIAMSON (2001), "Terms of Trade Shocks and Economic Performance 1870-1940: Prebisch and Singer Revisited," NBER Working Paper 8188, National Bureau of Economic Research, Cambridge, Mass. (March).

HALPERIN DONGHI, T. (1985), "Economy and Society in Post-Independence Spanish America.” In The Cambridge History of Latin America: Volume III: From Independence to c 1870, ed. by L. Bethell (Cambridge: Cambridge University Press).

HARLEY, C. K. (1988), "Ocean Freight Rates and Productivity, 1740-1913: The Primacy of Mechanical Invention Reaffirmed," Journal of Economic History 48 (December): 851-76. 
HATTON, T. J. and J. G. WILLIAMSON (1998), The Age of Mass Migration: Causes and Economic Impact (New York: Oxford University Press).

IBGE (1990), Estadísticas Históricas do Brasil: Series Econômicas, Demográficas e Sociais 1550 a 1988 , 2a edición.

IRWIN, D. A. (1997), "Higher Tariffs, Lower Revenues? Analyzing the Fiscal Aspects of the Great Tariff Debate of 1888," NBER Working Paper 6239, National Bureau of Economic Research, Cambridge, Mass. (October).

KINDLEBERGER, C. P. (1951), "Group Behavior and International Trade," Journal of Political Economy 59 (February): 30-46.

KRUGMAN, P. R. (1991), Geography and Trade (Cambridge, Mass.: MIT Press).

KRUGMAN, P. R. and A. VENABLES (1990), "Integration and the Competitiveness of Peripheral Industry." In Unity with Diversity in the European Community, ed. by C. Bliss and J. Braga de Macedo (Cambridge: Cambridge University Press).

--- (1995), "Globalization and the Inequality of Nations," NBER Working Paper 5098, National Bureau of Economic Research, Cambridge, Mass. (April).

LANDES, D. (1998), The Wealth and Poverty of Nations (New York: Norton).

LEFF, N. H. (1972), "Economic Development and Regional Inequality: Origins of the Brazilian Case," Quarterly Journal of Economics 86 (May): 243-62.

--- (1982), Underdevelopment and Development in Brazil: vol. 1, Economic Structure and Change, 1822-1947 and vol. 2, Reassessing the Obstacles to Economic Underdevelopment (London: George Allen and Unwin).

--- (1992), "Economic Development in Brazil, 1822-1913," First Boston Working Paper FB-92-02, Columbia University.

LEWIS, C. (1986), "Industry in Latin America before 1930." In The Cambridge History of Latin America: Volume IV: c 1870 to 1930, ed. by L. Bethell (Cambridge: Cambridge University Press). 
LEWIS, W. A. (1954), "Economic Development with Unlimited Supplies of Labour," Manchester School of Economic and Social Studies 22 (May): 139-91.

--- (1978), The Evolution of the International Economic Order (Princeton, NJ: Princeton University

Press).

MADDISON, A. (1995), Monitoring the World Economy 1820-1992 (Paris: OECD Development Centre Studies).

--- (2001), The World Economy. A Millennial Perspective (Paris: OECD Development Centre).

MARES, D. (2001), Violent Peace: Militarized Interstate Bargaining In Latin America (New York.

Columbia University Press).

MÁRQUEZ, G. (2002), “The Political Economy of Mexican Protectionism, 1868-1911.” PhD thesis, Harvard University (March).

MCGREEVEY. W. P. (1971), An Economic History of Colombia, 1845-1930 (Cambridge: Cambridge University Press).

MORENO FRAGINALS, M. (1986), "Plantation Economies and Societies in the Spanish, 1860-1930." In The Camdridge History of Latin America. Vol IV., c. 1870 to 1930, ed. by BETHELL, L. (Cambridge University Press).

NEWLAND, C. (1998), "Economic Development and Population Change: Argentina 1810-1870."In Latin America and the World Economy Since 1800, ed. by J. Coatsworth and A. Taylor (Cambridge, Mass.: Harvard University Press).

NORTH, D. C. (1958), "Ocean Freight Rates and Economic Development 1750-1913," Journal of Economic History 18 (December): 538-55.

NORTH, D., W. SUMMERHILL and B. WEINGAST (1998), “Order, Disorder and Economic Change. Latin America vs. North America.” Unpublished manuscript, Hoover Institution, Stanford University. OCAMPO, J.A. (1994), “Una breve historia cafetera de Colombia, 1830-1938.” In Miniagricultura 80 años. Transformaciones en la Estructura Agraria (Bogotá-Caracas-Quito: Tercer Mundo Editores). 
O'ROURKE, K. H. (1997), "The European Grain Invasion, 1870-1913," Journal of Economic History 57 (December): 775-801.

--- (2000), "Tariffs and Growth in the Late $19^{\text {th }}$ Century," Economic Journal 110 (April): 456-83.

O'ROURKE, K. H.; A. M. TAYLOR; and J. G. WILLIAMSON (1996), "Factor Price Convergence in the Late 19th Century," International Economic Review 37 (August): 499-530.

O'ROURKE, K. H. and J. G. WILLIAMSON (1999), Globalization and History (Cambridge, Mass.: MIT Press).

OVERMAN, H. G.; S. REDDING; and A. J. VENABLES (2001), "The Economic Geography of Trade, Production, and Income: A Survey of Empirics," unpublished paper, London School of Economics (August).

PREBISCH, R. (1950), The Economic Development of Latin America and Its Principal Problems (New York).

PRITCHETT, L. (1997), “Divergence, Big Time,” Journal of Economic Perspectives 11 (Summer): 3-18. REDDING, S. and A. J. VENABLES (2000), "Economic Geography and International Inequality," CEPR Discussion Paper 2568.

ROBINSON, J. (2000), "Are Endowments Fate?" paper presented at the Second Laclio Conference, Stanford University, Stanford, California (November).

ROGOWSKI, R. (1989), Commerce and Coalitions: How Trade Affects Domestic Political Alignments

(Princeton, NJ: Princeton University Press).

SÁNCHEZ-ALBORNOZ, N. (1986), “The Population of Latin America, 1850-1930.” In The Camdridge History of Latin America. Vol IV., c. 1870 to 1930, ed. by BETHELL, L. (Cambridge: Cambridge University Press).

SINGER, H. W. (1950), "The Distribution of Gains between Investing and Borrowing Countries," American Economic Review 11 (March): 473-85. 
STEMMER, J. E. O. (1989), "Freight Rates in the Trade between Europe and South America," Journal of Latin American Studies 21, pt. 1 (February): 22-59.

SUNKEL, O. and P. PAZ (1982), El Subdesarrollo Latinoamericano y la Teoría del Desarrollo (16 a), (México).

TAYLOR, A. M. (1994), "Mass Migration to Distant Southern Shores: Argentina and Australia 18701939." In Migration and the International Labor Market 1850-1939, edited by T. J. Hatton and J. G. Williamson (London: Routledge):

TAYLOR, A. M. (1998), "On the Costs of Inward-Looking Development: Price Distortions, Growth, and Divergence in Latin America," Journal of Economic History 58 (March): 1-28.

UNITED NATIONS, ECLA (1966), The Process of Industrial Development in Latin America. (New York: United Nations, Economic Commission for Latin America).

VAZQUEZ PRESEDO, V. (1988), Estadísticas Históricas Argentinas. Compendio 1873-1973 (Buenos Aires: Academia Nacional de Ciencias Económicas).

WILLIAMSON, J. G. (1997), "Globalization and Inequality, Past and Present,” World Bank Research Observer 12 (April): 117-35.

— (1998), "Growth, Distribution and Demography: Some Lessons from History," Explorations in Economic History 35 (July): 241-71.

- (1999), "Real Wages, Inequality, and Globalization in Latin America before 1940," Revista de Historia Economica, 17, special number: 101-42.

- (2002), "Land, Labor, and Globalization in the Third World, 1870-1940," Journal of Economic History 62 (March): 55-85. 
Table 1

Relative Levels of GDP per capita and Real Wages in Latin America 1870-1940

\begin{tabular}{lccc}
\hline & Latin America & European Core & Latin Europe \\
\hline 1. GDP per capita (UK=100) & & & \\
1870 & 38 & 72 & 39 \\
1890 & 37 & 73 & 39 \\
1900 & 34 & 77 & 38 \\
1913 & 42 & 82 & 40 \\
1929 & 47 & 91 & 48 \\
1940 & 35 & 78 & 40 \\
& & & \\
2. PPP real wages (UK=100) & & & 45 \\
& & 87 & 40 \\
1870 & 56 & 86 & 36 \\
1890 & 45 & 84 & 48 \\
1900 & 45 & 88 & 55 \\
1913 & 52 & 93 & \\
1929 & 62 & 83 & \\
1940 & 70 & & \\
\end{tabular}

Source: See text.

Notes: European Core consists of Britain, France, and Germany. Latin Europe consists of Italy, Portugal, and Spain. 
Table 2

\section{Population in Different Latin American Regions} 1870-1930

\begin{tabular}{|c|c|c|c|c|c|}
\hline & \multicolumn{5}{|c|}{ Growth } \\
\hline & \multicolumn{2}{|c|}{ Population (000) } & \multirow{2}{*}{$\begin{array}{c}\text { Rate } \\
\%\end{array}$} & \multicolumn{2}{|c|}{ Share of LA } \\
\hline & 1850 & 1930 & & 1850 & 1930 \\
\hline \multicolumn{6}{|l|}{ Settler Regions } \\
\hline Argentina & 1100 & 11936 & 3.0 & 4 & 11 \\
\hline Brazil SE & 2178 & 17755 & 2.7 & 7 & 17 \\
\hline Uruguay & 132 & 1599 & 3.2 & 0 & 2 \\
\hline Sub-total & 3410 & 31290 & 2.8 & 11 & 30 \\
\hline \multicolumn{6}{|l|}{ Tropical Regions } \\
\hline Brazil (others) & 7098 & 31969 & 1.9 & 23 & 31 \\
\hline Costa Rica & 101 & 499 & 2.0 & 0 & 0 \\
\hline Cuba & 1186 & 3837 & 1.5 & 4 & 4 \\
\hline Dominican Republic & 146 & 1227 & 2.7 & 0 & 1 \\
\hline Haití & 938 & 2422 & 1.2 & 3 & 2 \\
\hline Panamá & 135 & 502 & 1.7 & 0 & 0 \\
\hline Puerto Rico & 495 & 1552 & 1.4 & 2 & 1 \\
\hline Sub-total & 10099 & 42008 & 1.8 & 33 & 40 \\
\hline \multicolumn{6}{|l|}{ Highland Regions } \\
\hline Bolivia & 1374 & 2153 & 0.6 & 5 & 2 \\
\hline Chile & 1443 & 4365 & 1.4 & 5 & 4 \\
\hline Colombia & 2065 & 7350 & 1.6 & 7 & 7 \\
\hline Ecuador & 816 & 2160 & 1.2 & 3 & 2 \\
\hline El Salvador & 366 & 1443 & 1.7 & 1 & 1 \\
\hline Guatemala & 850 & 1771 & 0.9 & 3 & 2 \\
\hline Honduras & 350 & 948 & 1.3 & 1 & 1 \\
\hline Mexico & 7662 & 16589 & 1.0 & 25 & 16 \\
\hline Nicaragua & 300 & 742 & 1.1 & 1 & 1 \\
\hline Perú & 2001 & 5651 & 1.3 & 7 & 5 \\
\hline Venezuela & 1490 & 2950 & 0.9 & 5 & 3 \\
\hline Sub-total & 18717 & 46122 & 1.1 & 61 & 44 \\
\hline Total & $\underline{30530}$ & 104144 & $\underline{1.5}$ & 100 & 100 \\
\hline
\end{tabular}

Source: Sanchez Albornoz (1986:Table 1) and IBGE (1990: Tables 1.3 and 1.7) for Brazil. 
Table 3

Structure of world production or exports of primary products between Latin America and high-income or low-income competitors, 1913.

\section{LA $\begin{gathered}\text { High } \\ \text { Income }\end{gathered} \quad \begin{aligned} & \text { Low } \\ & \text { Income }\end{aligned}$}

Settler Regions (based on world exports)

$\begin{array}{lcccc}\text { Wool } & 20 & 67 & 12 & 100 \\ \text { Cattle } & 30 & 51 & 18 & 100 \\ \text { linseed } & 42 & 34 & 24 & 100 \\ \text { maize } & 43 & 53 & 4 & 100 \\ \text { wheat } & 15 & 76 & 10 & 100 \\ \text { wheat flower } & 6 & 86 & 6 & 98 \\ \text { average } & \mathbf{2 6} & \mathbf{6 1} & \mathbf{1 2} & \mathbf{1 0 0}\end{array}$

Tropical Regions (based on world exports)

$\begin{array}{lllll}\text { Sugar } & 29 & 39 & 27 & 95 \\ \text { Cacao } & 42 & 10 & 34 & 86 \\ \text { Rubber } & 34 & 39 & 25 & 98 \\ \text { Coffee } & 82 & 12 & 5 & 99 \\ \text { average } & \mathbf{4 7} & \mathbf{2 5} & \mathbf{2 3} & \mathbf{9 5}\end{array}$

Highland Regions (based on world production)

$\begin{array}{lcccc}\text { Copper } & 9 & 84 & 7 & 100 \\ \text { Tin } & 20 & 10 & 70 & 100 \\ \text { Silver } & 38 & 59 & 3 & 100 \\ \text { Gold } & 17 & 37 & 46 & 100 \\ \text { Lead } & 5 & 93 & 2 & 100 \\ \text { Nitrates } & 97 & 3 & & 100 \\ \text { average } & \mathbf{3 1} & \mathbf{4 8} & \mathbf{2 6} & \mathbf{1 0 0}\end{array}$

Notes: Latin America from Bulmer-Thomas (1994: Table 6.3).

High-income competitors: Europe, USA, Canada and Australasia.

Low-income competitors: Asia and Africa.

All averages are unweighted. 
Table 4

\section{Exports Per Capita in US Dollars: three-year averages}

$\begin{array}{lccc} & \mathbf{1 8 7 0} & \mathbf{1 9 1 2} & \text { Increment \% } \\ \text { Settler Regions } & 32 & 56 & 78 \\ \text { Tropical Regions } & 15 & 28 & 90 \\ \text { Highland Regions } & 7 & 13 & 81 \\ \text { Latin America } & \mathbf{9} & \mathbf{2 0} & \mathbf{1 2 9} \\ & & & \\ \text { Australia } & 63 & 87 & 37 \\ \text { Canada } & 20 & 52 & 160 \\ \text { NZ } & 97 & 99 & 2 \\ \text { US } & 10 & 25 & 150 \\ \text { Average above four } & \mathbf{4 0} & \mathbf{5 7} & \mathbf{4 2}\end{array}$

Notes: Estimates on the basis of national data provided by Bulmer-Thomas (1994: Table 3.5). 


\title{
Table 5
}

\section{Tariff Impact on GDP per capita Growth by Region}

\author{
5-Year Overlapping Average Growth Rate
}

Dependent Variable:

1875-1908

1924-1934

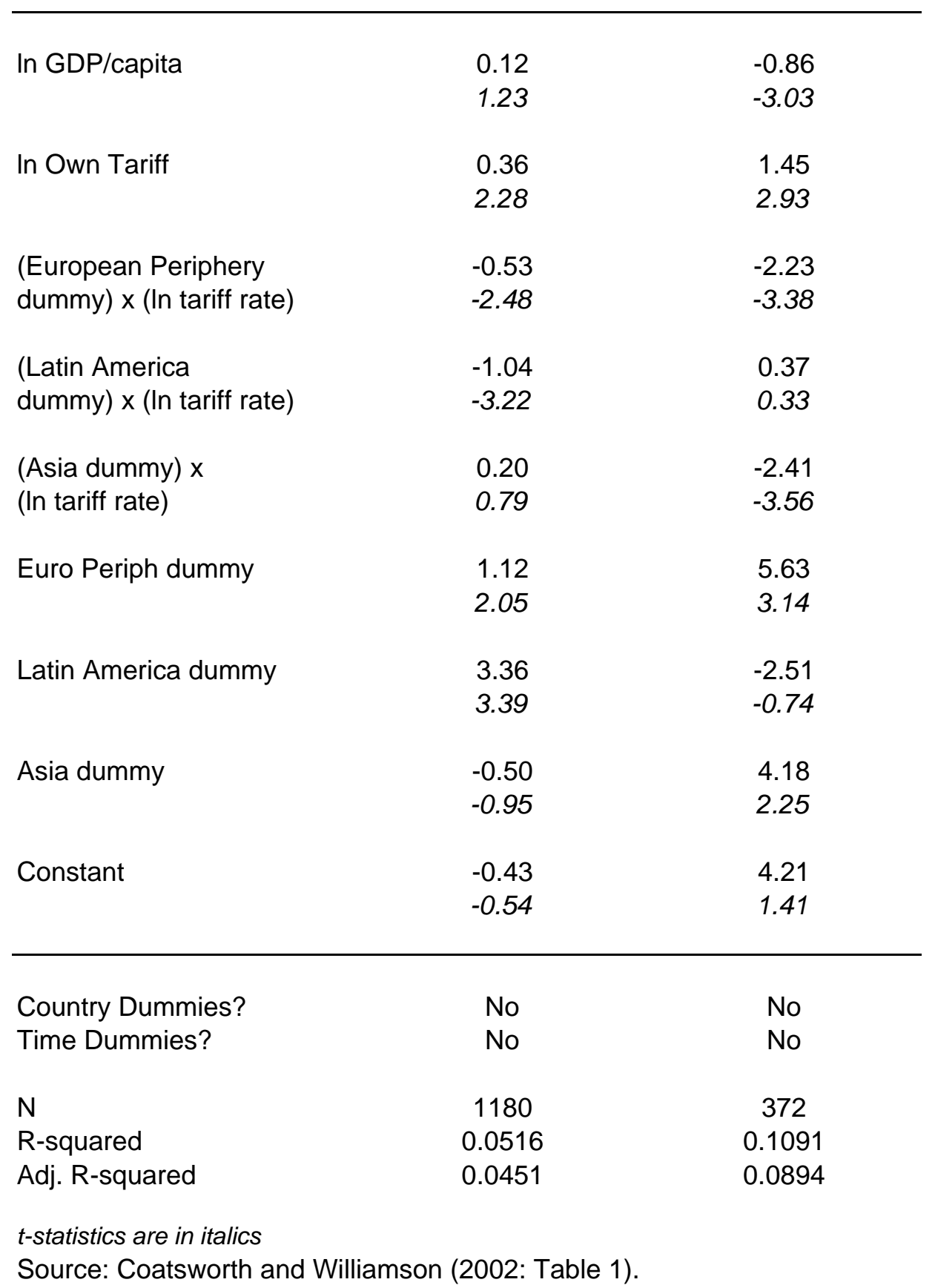


Table 6

Wage/Rental Ratio Trends in the Resource-Abundant Periphery 1870-1939 (1911=100)

\begin{tabular}{crrrrrrrr}
\hline Period & Argentina & Uruguay & Burma & Siam & Egypt & Punjab & Australia & USA \\
\hline $1870-1874$ & & & & & & & & \\
$1875-1879$ & & 1112.5 & & 4699.1 & & 196.7 & 416.2 & 233.6 \\
$1880-1884$ & 580.4 & 728.3 & & 3108.1 & 174.3 & 198.5 & 253.0 & 195.0 \\
$1885-1889$ & 337.1 & 400.2 & & 2331.6 & 541.9 & 150.8 & 216.3 & 182.1 \\
$1890-1894$ & 364.7 & 377.2 & 190.9 & 1350.8 & 407.5 & 108.7 & 136.2 & 173.5 \\
$1895-1899$ & 311.1 & 303.6 & 189.9 & 301.3 & 160.1 & 92.0 & 147.7 & 175.0 \\
$1900-1904$ & 289.8 & 233.0 & 186.8 & 173.0 & 166.7 & 99.8 & 130.0 & 172.4 \\
$1905-1909$ & 135.2 & 167.8 & 139.4 & 57.2 & 64.4 & 92.4 & 97.9 & 132.7 \\
$1910-1914$ & 84.0 & 117.9 & 106.9 & 109.8 & 79.8 & 80.1 & 100.6 & 101.1 \\
$1915-1919$ & 53.6 & 120.8 & 164.7 & 202.1 & 83.5 & 82.5 & 111.0 & 124.7 \\
$1920-1924$ & 53.1 & 150.3 & 113.6 & 157.9 & 124.3 & 81.1 & 137.2 & 122.4 \\
$1925-1929$ & 51.0 & 150.2 & & 114.9 & 120.8 & 72.6 & 115.1 & 160.1 \\
$1930-1934$ & 58.4 & 174.3 & & 113.1 & 116.2 & 50.4 & 98.3 & 165.2 \\
$1935-1939$ & 59.5 & 213.5 & & 121.6 & 91.0 & 33.2 & 110.5 & 240.1 \\
& & & & & & & & \\
\hline
\end{tabular}

Source: Williamson (2002: Tables 3 and 4) 
Figure 1 Real Freight Rate Indexes 1741-1913

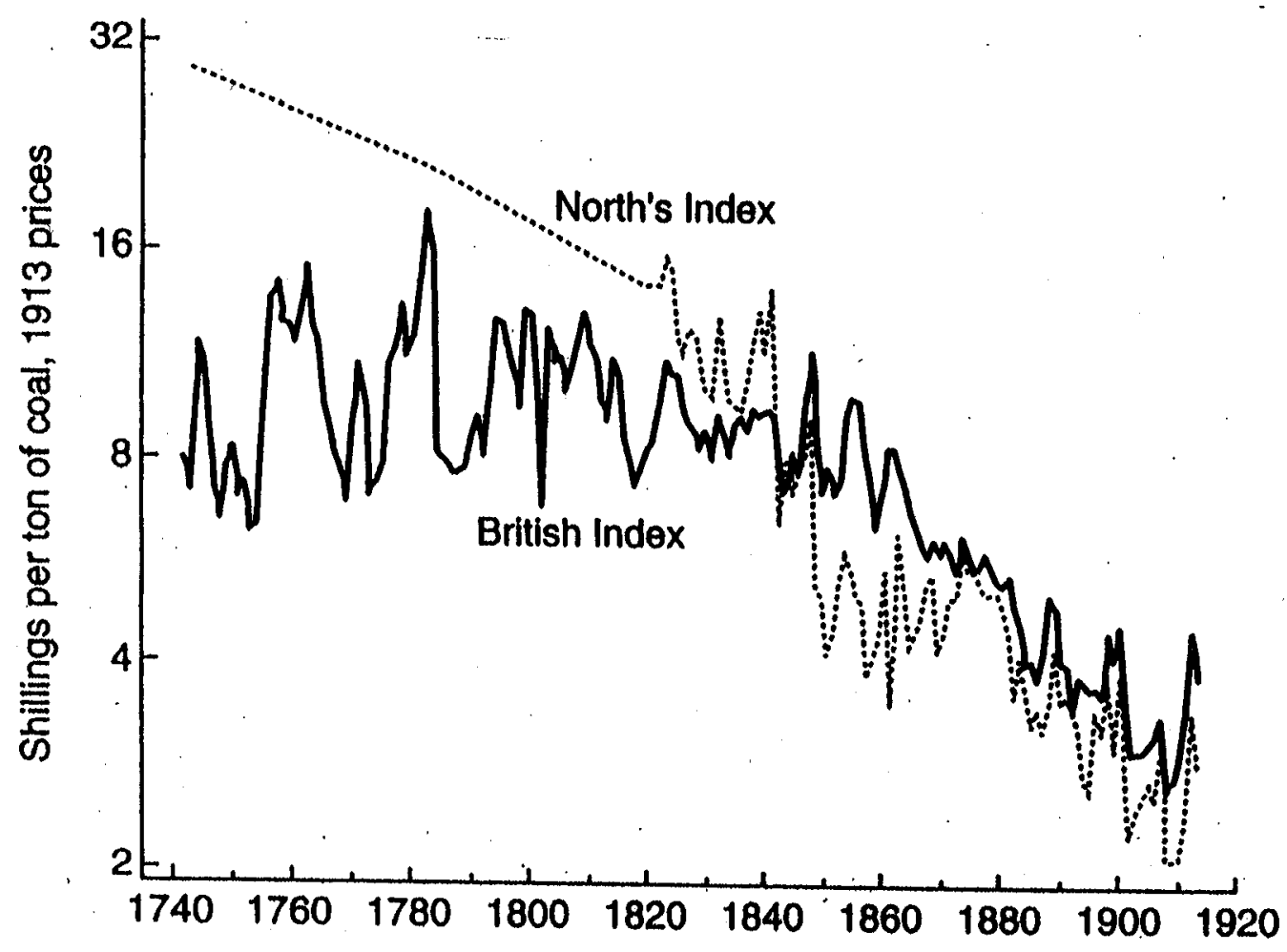

Source: Harley (1988: Figure 1). 
Figure 2 Latin America's Terms of Trade 1820-1950

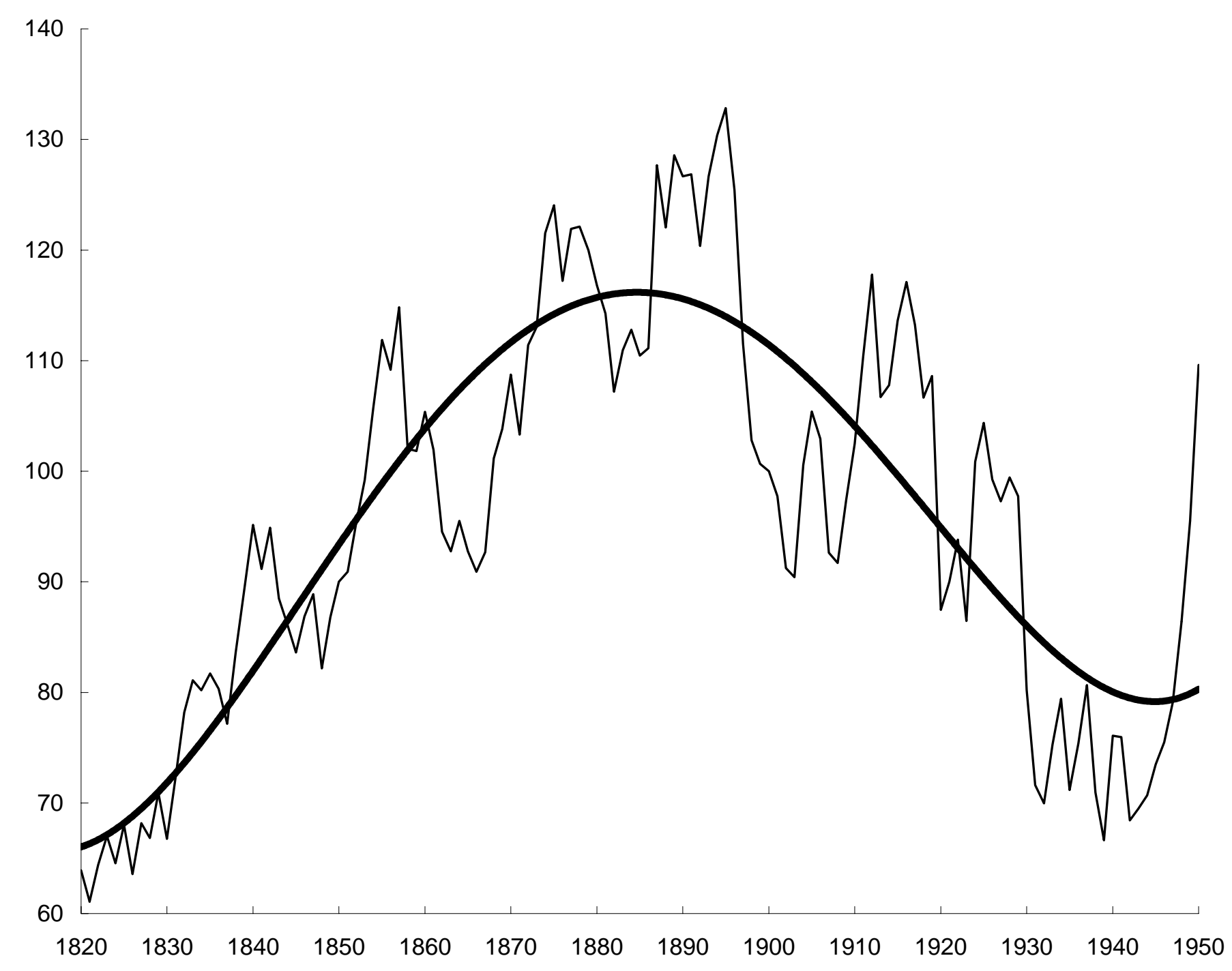


Figure 3 Average World Tariffs Before 1950

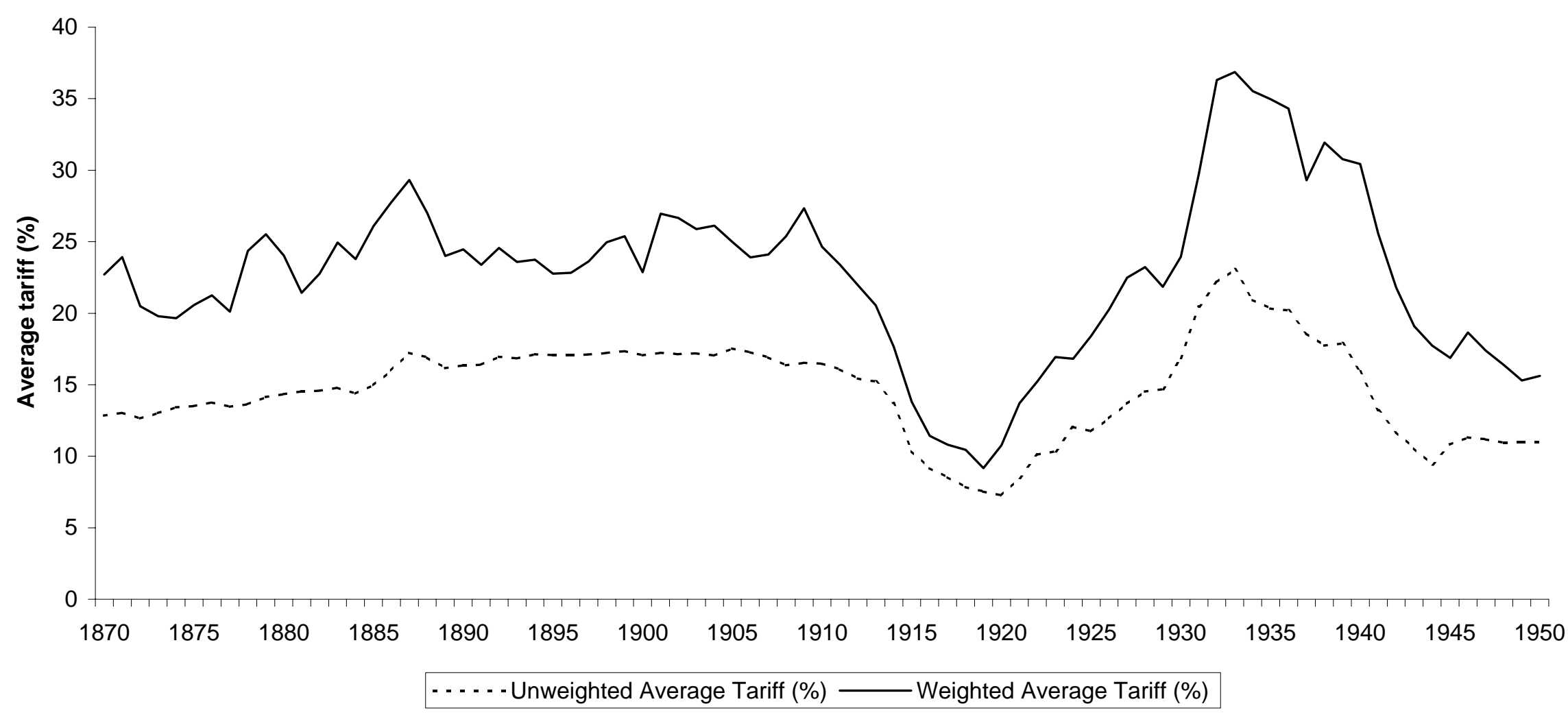

Source: Coatsworth and Williamson (2002: Figure 1). 
Figure 4 Unweighted Average of Regional Tariffs Before 1939

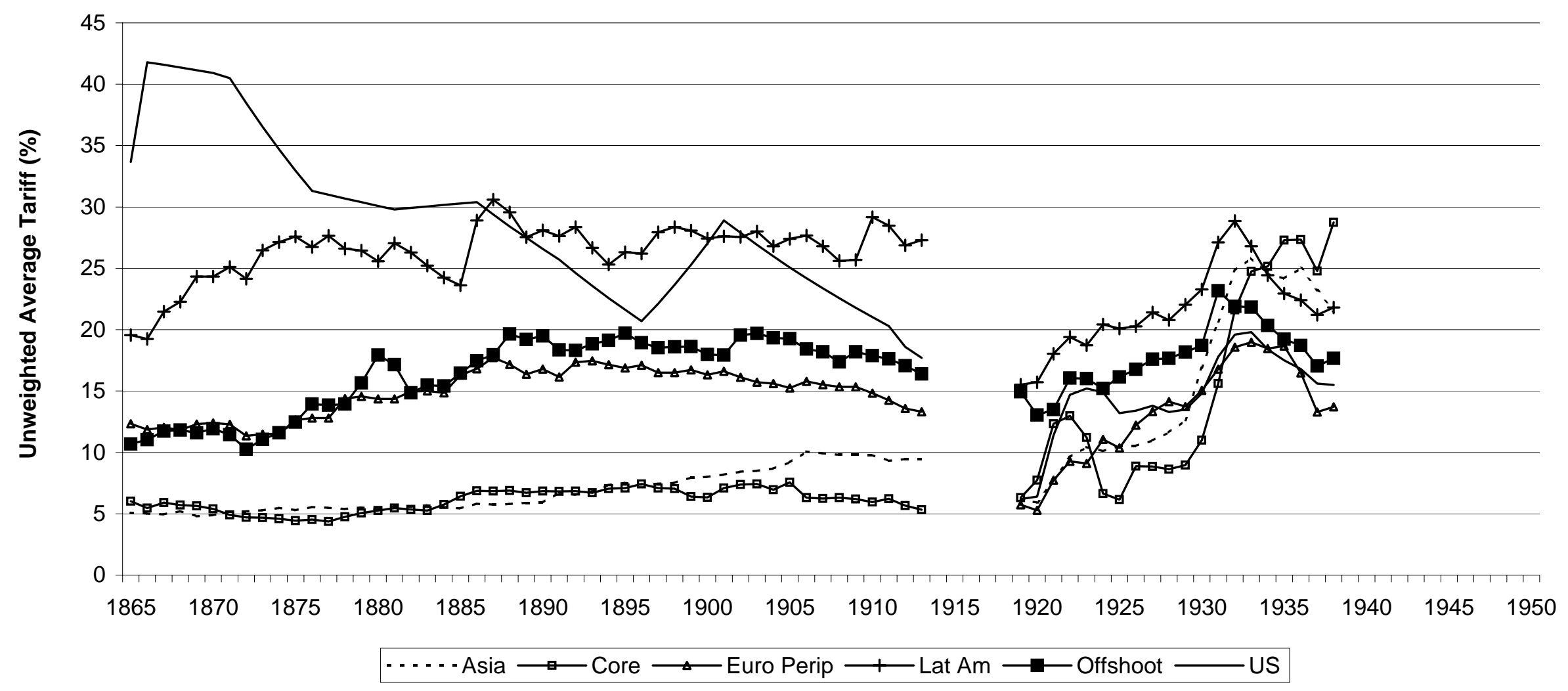

Source: Coatsworth and Williamson (2002: Figure 2). 